\title{
Ownership Structure and Financial Constraints: Evidence from a Structural Estimation
}

\author{
Chen Lin \\ Chinese University of Hong Kong \\ chenlin@baf.msmail.cuhk.edu.hk \\ Yue Ma \\ Lingnan University, Hong Kong \\ yuema@ln.edu.hk \\ Yuhai Xuan \\ Harvard Business School \\ yxuan@hbs.edu
}

Forthcoming in the Journal of Financial Economics

\begin{abstract}
This article examines the impact of the divergence between corporate insiders' control rights and cashflow rights on firms' external finance constraints via generalized method of moments estimation of an investment Euler equation. Using a large sample of U.S. firms during the 1994-2002 period, we find that the shadow value of external funds is significantly higher for companies with a wider insider controlownership divergence, suggesting that companies whose corporate insiders have larger excess control rights are more financially constrained. The effect of insider excess control rights on external finance constraints is more pronounced for firms with higher degrees of informational opacity and for firms with financial misreporting, and is moderated by institutional ownership. The results show that the agency problems associated with the control-ownership divergence can have a real impact on corporate financial and investment outcomes.
\end{abstract}

JEL Classifications: G31; G32; G34

Keywords: Ownership structure; Insider excess control rights; Financial constraints.

${ }^{*}$ We are grateful to Ben Esty, Stuart Gilson, Paul Gompers, Joy Ishii, Bill Schwert (the editor), Andrei Shleifer, Jeremy Stein, Belen Villalonga, and an anonymous referee for helpful suggestions and comments. Lin and Xuan acknowledge financial support from the Chinese University of Hong Kong and the Division of Research of the Harvard Business School, respectively. 


\section{Introduction}

Recent research in corporate ownership and control has documented a divergence between the control rights and cash-flow rights of corporate insiders in many publicly traded firms around the world (e.g., La Porta et al., 1999). Corporate officers and directors often have voting rights substantially in excess of their cash-flow rights, and in many cases, have effective control over all corporate decisions with disproportionately small economic interest in the firm (Gompers et al., 2010). In such firms, the classic agency conflict between managers and shareholders (Jensen and Meckling, 1976) is exacerbated to a conflict between corporate insiders and outside investors since the corporate insiders have the incentives and ability to divert corporate resources for private benefits at the expense of other investors (Shleifer and Vishny, 1997; Djankov et al., 2008). In line with this view, numerous studies have shown a negative relationship between the control rights-cash-flow rights deviation and corporate valuation in various countries and settings. ${ }^{1}$

While previous studies have tackled the question of whether the divergence between control rights and cash-flow rights (the “control-ownership divergence”) affects corporate values, the specific channels behind this relationship are largely unknown. Intuitively, it seems quite implausible that the large valuation discounts noted in the literature in firms with separation of ownership and control are solely driven by direct expropriation activities. In this paper, we identify an important mechanism through which the insider control-ownership divergence may affect firm values, and show that insider ownership structure has a real impact on corporate financial and investment outcomes. Specifically, using generalized method of moments estimation of an investment Euler equation proposed by Whited and Wu (2006), we examine the impact of the excess control rights of corporate insiders on firms' external finance constraints. External finance is a particularly important channel to investigate because financial constraints

\footnotetext{
${ }^{1}$ Gompers et al. (2010) provide a recent review of this literature.
} 
prevent firms from funding all desired investment (Stein, 2003; Billett et al., 2011). As a result, financially constrained firms might be forced to forgo significant investment projects with positive net present values. In fact, Whited and Wu (2006) find that the most financially constrained firms (by quartile) invest 18\% less than the least constrained ones.

Corporate finance theories provide a straightforward motivation for the connection between corporate insiders' control-ownership divergence and firms' financing constraints. In pursuit of private benefits, corporate insiders and controlling shareholders may seek to expropriate other investors, including minority shareholders and creditors, through various selfdealing activities including outright theft, transfer pricing, investor dilution, executive perquisite, expropriation of corporate opportunities, investment in unprofitable projects for self-interest, asset sales to insiders or affiliated corporations at favorable prices, loan guarantees using the firm's assets as collateral, and other self-serving financial transactions (Shleifer and Vishny, 1997; La Porta et al., 2000; Johnson, et al., 2000a; Djankov et al., 2008). The "private benefits of control" are reflected by the widely documented premium at which shares with superior voting rights trade (Shleifer and Vishny, 1997). Relevant evidence has been shown not only in developing countries where investor protection might be poor, but also in many developed countries including the U.S. ${ }^{2}$ In extreme cases, as pointed out by Friedman et al. (2003), many bankruptcy cases in both developing and developed countries have been associated with complete looting by corporate insiders and controlling shareholders, leaving the minority shareholders and creditors almost nothing when the firms went bankrupt. Corporate insiders' incentives to engage in self-dealing activities are especially strong when they have control rights in excess of cash-flow rights, as the excess control rights afford them the ability to do so while bearing a relatively small proportion of the financial consequence (Shleifer and Vishny, 1997; Johnson et al., 2000a). Masulis et al. (2009) find evidence that insiders with excess control rights waste corporate resources at the expense of shareholders in the pursuit of private benefits.

\footnotetext{
${ }^{2}$ The evidence has been shown in various contexts including the U.S. savings and loan crisis (Akerlof and Romer, 1993), the Mexican and Asian financial crises (La Porta et al., 2003; Johnson et al., 2000b), and legal disputes over self-dealing in France, Italy, Belgium, and Germany (Johnson et al., 2000a).
} 
Moreover, in effect, the insider control-ownership divergence often creates an extreme example of antitakeover protection (Gompers et al., 2010). The problem of expropriation by insiders is aggravated in such firms without valid takeover threats, as corporate insiders with large control rights get entrenched and managerial discretion cannot be effectively controlled (Jensen, 1993; Shleifer and Vishny, 1997).

In anticipation of the potential expropriation by corporate insiders in firms with a divergence between control rights and cash-flow rights, outside investors (both shareholders and creditors) are less willing to invest in these firms because they face the risk that the returns on their investment will never materialize (La Porta et al., 2000). As a direct consequence, such firms become financially more constrained due to the very costly or even lack of access to external finance. Despite the theoretical appeal, to the best of our knowledge, no study has examined the link between the control-ownership divergence and external financing constraints.

In this paper, we fill this gap by examining the relationship between the controlownership divergence of a firm's corporate insiders and the firm's external finance constraints using a newly available data set on insider ownership structure of U.S. firms over the period 1994 to 2002. Following Whited and Wu (2006), we take a structural approach and explore this relationship by estimating the Euler equation of a standard intertemporal investment model augmented to account for financial constraints. Indeed, Whited (1992) shows that the augmentations of the investment equation improve its fit. The basic idea is that finance constraints affect the intertemporal substitution of investment today for investment tomorrow through the shadow value of external funds. Intuitively, firms that are financially constrained have investment growth that is too high given their current profitability because they put off projects with positive net present values into the future; that is, they behave as if they have a high discount rate. Therefore, investment today is too low relative to investment tomorrow. The shadow value of external funds can be parameterized as a function of observable firm and industry characteristics, and the parameters can be estimated via generalized method of moments (GMM) estimation. The fitted value of the shadow value will be a measure of external finance 
constraints (Whited and $\mathrm{Wu}, 2006$ ). By modifying the specification for the shadow value to include insider ownership structure, we can test whether the insider control-ownership divergence affects financial constraints by examining the relevant parameter estimate as well as the overall model suitability.

The structural approach employed in the paper has significant advantages over the alternative test for financial constraints based on reduced-form regressions of investment on Tobin's $q$ and cash flow in which the investment-cash flow sensitivity from the regression results is interpreted as a measure of financial constraints (e.g., Fazzari et al., 1988). If investment opportunities are measured with error, the positive link between investment and cash flow in such regressions may arise not because of financial constraints, but merely because cash flow captures the quality of investment opportunities. Indeed, Tobin's $q$ contains a great deal of measurement error as a proxy for investment opportunities (Erickson and Whited, 2000). ${ }^{3}$ Furthermore, from a theoretical standpoint, using investment-cash flow sensitivity to proxy for financial constraints has also been demonstrated to be flawed, as curvature in the profit function can result in a discrepancy between marginal and average $q$, which gives cash flow independent predictive power in investment regressions even if financing is frictionless (e.g., Hennessy and Whited, 2007). In contrast, as Whited and Wu (2006) point out, the most significant advantage of the investment Euler equation approach is its avoidance, via structural estimation, of serious estimation problems that plague reduced-form regressions including simultaneity and measurement errors. We therefore opt for this approach in our analysis of the relationship between insider ownership structure and external finance constraints.

Our results indicate that the shadow value of external funds is significantly higher at companies with a wider divergence between corporate insiders' control rights and cash-flow rights. The coefficients on various measures of insider ownership structure are all positive and highly statistically significant, indicating that companies whose corporate insiders have larger

\footnotetext{
${ }^{3}$ The structural approach based on the investment Euler equation has an advantage of avoiding the measurement error problem because it does not require the measure of marginal $q$ in estimation.
} 
excess control rights are more financially constrained. Moreover, the model specification tests of the overidentifying restrictions imply that models including measures of insider ownership structure are not misspecified. The effect of insider ownership structure on financing constraints remains strong and significant after controlling for a series of firm characteristics shown in the existing literature that affect firm financial constraints. Our results suggest that insider ownership structure is an important factor that influences external finance constraints, and the results are consistent with the hypothesis that the excess control rights of a firm's corporate insiders increase the likelihood of insider expropriation of other investors and therefore intensify the firm’s external financial constraints.

We then investigate the factors that influence the relationship between insider ownership structure and external finance constraints. Our goal is to understand in what situations the divergence between insider control rights and cash-flow rights most severely affects financial constraints and to shed light on how such effects might be mitigated. We examine the following set of factors: firm informational opacity, financial restatement and misreporting, and institutional ownership. To implement the empirical estimation, we include these factors and their interactions with the measure for insider ownership structure in the specification for the shadow value of external funds and re-estimate the Euler equation. If the effect of insider ownership structure on external finance constraints is driven by potential expropriation risk, we should expect to see a more pronounced effect in situations where insiders with excess control rights are more likely to engage in self-dealing or expropriation activities.

The results from these estimations indicate that the effect of the insider control-ownership divergence on financial constraints is more pronounced for firms with higher degrees of informational opacity. Specifically, it is particularly strong for small firms, firms without debt ratings, firms that are not included in the Standard \& Poor's (S\&P) 500 stock index, and firms with relatively meager analyst coverage. The effect is also greater for firms with financial restatements, especially for those involved in fraudulent misreporting. Finally, we find that the shadow value of external funds is significantly and negatively associated with firms' institutional 
ownership. More interestingly, we find that institutional ownership weakens the relationship between the insider control-ownership divergence and external finance constraints, indicating the monitoring role of institutional investors on potential expropriation activities of corporate insiders.

Taken together, our results suggest that the divergence between insider control rights and cash-flow rights aggravates the risks of potential expropriation of outside shareholders and creditors by a firm's corporate insiders and thereby increases the firm's external finance constraints. We find such evidence of finance constraints by examining observed real investment decisions. Therefore, we report real effects of the agency problems associated with the control-ownership divergence and show that ownership structure can have a real impact on corporate financial and investment outcomes. This paper contributes to a number of related literatures. First, the paper adds to the classical yet growing literature on ownership and control (e.g., La Porta et al., 1999; Claessens et al., 2000; Gompers et al., 2010; Lin et al., 2011) by linking insider excess control rights to external finance constraints. This sheds direct light on the valuation discount shown in the literature by demonstrating the mechanism through which the control-ownership divergence may affect firm values. More specifically, the observed valuation losses in firms with divergent control and cash-flow rights are not just from their difficulty in obtaining external finance, but also from the distorted real investment decisions brought about by these finance constraints. These results also contribute to the literature on self-dealing and expropriation (e.g., Johnson et al., 2000a; La Porta et al., 2000; Djankov et al., 2008) by showing the real corporate outcomes caused by insiders' potential expropriation and self-dealing activities. Last but not least, our paper adds to the literature on financial constraints (e.g., Kaplan and Zingales, 1997, and Whited and $\mathrm{Wu}, 2006)^{4}$ and shows that ownership structure is an important determinant of financial constraints.

\footnotetext{
${ }^{4}$ Stein (2003) provides a comprehensive review of this literature.
} 
The remainder of the paper proceeds as follows. Section 2 describes the specification and estimation methodology for the structural model of investment and external financial constraints. Section 3 discusses the data and variables and presents summary statistics. Section 4 presents the empirical results. Section 5 concludes.

\section{Model specification and estimation methodology}

In this section, we briefly outline the specification and estimation methodology for the structural model of investment and external finance constraints. Following the pioneering work of Whited (1992), we adopt the Euler equation approach to estimate the extent of financing constraints. This structural model approach is based on the dynamic optimization theory of the investment Euler equation. As discussed in the introduction, the structural approach to estimate financial constraints has significant advantages over the alternative investment-cash flow sensitivity estimation from reduced-form regressions as it avoids serious sample selection, simultaneity, and measurement-error problems. This section closely follows Whited (1992) and Whited and Wu (2006), which provide more detailed derivations and discussions.

Suppose firm $i$ maximizes the following objective function (given by Eq. (1)), subject to the dividend identity (Eq. (2)) and the dynamic investment constraints (Eq. (3)):

$$
W_{i 0}=\max E_{i 0} \sum_{t=0}^{\infty} \rho_{0, t} D_{i t}
$$

subject to

$$
\begin{aligned}
& D_{i t}=\varphi\left(K_{i t}, v_{i t}\right)-C\left(I_{i t}, K_{i t}\right)-I_{i t}+B_{i, t+1}-\left(1+r_{t}\right) B_{i t} \\
& K_{i, t+1}=I_{i t}+\left(1-\delta_{i}\right) K_{i t} .
\end{aligned}
$$

In Eq. (1), $W_{i 0}$ is the present-value of firm $i$ at time $0 ; E_{i 0}$ is the expectation operator conditional on firm $i$ 's information set at time $0 ; \rho_{0, t}$ is the discount factor from time 0 to $t$; and $D_{i t}$ is firm $i$ 's dividends at time $t$. In Eq. (2), $\varphi\left(K_{i t}, v_{i t}\right)$ is the restricted profit function that is maximized with respect to variable costs, with $K_{i t}$ denoting firm $i$ 's capital stock at time $t$ and $v_{i t}$ denoting the 
productivity shock; $C\left(I_{i t}, K_{i t}\right)$ is the adjustment cost of investment, with $I_{i t}$ denoting firm $i$ 's investment at time $t$; $B_{i t}$ and $r_{t}$ are firm $i$ 's stock of debt and its coupon rate at time $t$, respectively. In Eq. (3), $\delta_{i}$ is firm $i$ 's depreciation rate of the capital stock.

The financial frictions are introduced via a constraint on dividends in Eq. (4) below:

$$
D_{i t} \geq D_{i t}^{*}
$$

where $D_{i t}^{*}$ is the lower bound on dividends of the firm. ${ }^{5}$

The estimation hinges on the identification of the Lagrange multiplier on the dividends constraint, denoted as $\lambda_{i t}$, via the Euler equation governing the capital stock. This multiplier is equal to the shadow value of scarce external funds, or the shadow cost associated with raising new external equity financing. Hence, a higher value of $\lambda_{i t}$ indicates a higher cost of external financing. The shadow cost of external finance is zero, which implies $\lambda_{i t}=0$, if the external financing constraint is not binding.

The Euler equation is obtained from the first-order condition with respect to investment expenditure:

$$
E_{i t} \rho_{t, t+1} \Lambda_{i . t+1}\left[\left(\frac{\partial \varphi}{\partial K_{i, t+1}}-\frac{\partial C}{\partial K_{i, t+1}}\right)+\left(1-\delta_{i}\right)\left(\frac{\partial C}{\partial I_{i, t+1}}+1\right)\right]=\frac{\partial C}{\partial I_{i t}}+1
$$

where $\frac{\partial C}{\partial I_{i t}}$ is the marginal adjustment cost of investment, $\frac{\partial \varphi}{\partial K_{i, t+1}}-\frac{\partial C}{\partial K_{i, t+1}}$ is the marginal "net profit” of capital, and $\Lambda_{i . t+1}=\frac{1+\lambda_{i . t+1}}{1+\lambda_{i t}}$, which is the relative shadow cost of external finance.

The Euler Eq. (5) indicates that the marginal adjustment and purchasing costs of investing today (on the right-hand side) should be equal to the discounted marginal cost of postponing investment to tomorrow (on the left-hand side). In other words, the optimal

\footnotetext{
${ }^{5}$ Whited (1992) and Whited and Wu (2006) include one more external finance constraint, namely the upper bound on the stock of debt, but they point out that since it is difficult to separate the identification of the Lagrange multipliers on the dividends constraint and on the debt constraint, they only focus on the identification of the Lagrange multiplier on the dividends constraint in their estimation.
} 
investment decision of a firm should be made such that, on the margin, it must be indifferent between investing today and waiting and transferring those resources to invest tomorrow.

To estimate the Euler Eq. (5), Whited and Wu (2006) make the following assumptions on the marginal restricted profit of capital (defined by Eq. (6)) and on the real adjustment cost of investment (defined by Eq. (7)):

$$
\begin{aligned}
& \frac{\partial \varphi}{\partial K_{i t}}=\frac{Y_{i t}-\mu C_{i t}}{K_{i t}} \\
& C\left(I_{i t}, K_{i t}\right)=\left[\alpha_{0}+\sum_{m=2}^{3} \frac{\alpha_{m}}{m}\left(\frac{I_{i t}}{K_{i t}}\right)^{m}\right] K_{i t} .
\end{aligned}
$$

In the above equations, $Y_{i t}$ and $C_{i t}$ are firm $i$ 's output and variable costs at time $t$, respectively; $\mu$ is a constant mark-up; and $\alpha_{m}(m=2,3)$ are parameters to be estimated. ${ }^{6}$

Using Eq. (6) and Eq. (7) and replacing the expectations operator with an expectational error, $\varepsilon_{i, t+1}$, which is uncorrelated with any information known at time $t$, we can rewrite Eq. (5) as:

$$
\begin{aligned}
& \rho_{t, t+1}\left(\frac{1+\lambda_{i . t+1}}{1+\lambda_{i t}}\right)\left\{\left[\frac{Y_{i . t+1}-\mu C_{i . t+1}}{K_{i . t+1}}-\alpha_{0}+\sum_{m=2}^{3} \frac{(m-1) \alpha_{m}}{m}\left(\frac{I_{i . t+1}}{K_{i . t+1}}\right)^{m}\right]+\left(1-\delta_{i}\right)\left[\sum_{m=2}^{3} \alpha_{m}\left(\frac{I_{i . t+1}}{K_{i . t+1}}\right)^{m-1}+1\right]\right\} \\
& =\sum_{m=2}^{3} \alpha_{m}\left(\frac{I_{i t}}{K_{i t}}\right)^{m-1}+1+\eta_{i}+\xi_{t}+\varepsilon_{i, t+1},
\end{aligned}
$$

where we also added an unobserved firm fixed effect $\left(\eta_{i}\right)$ and a time fixed effect $\left(\xi_{t}\right)$ to capture the macroeconomic business cycle.

Eq. (8) is the estimating equation that can be estimated with specifications from Whited and $\mathrm{Wu}$ (2006) for the stochastic discount factor $\left(\rho_{t, t+1}\right)$ and for the unobservable shadow cost of external finance $\left(\lambda_{i, t+1}\right)$.

The stochastic discount factor is specified by the three-factor Fama and French (1993) model:

\footnotetext{
${ }^{6}$ Following Whited and Wu (2006), we set the highest power at $m=3$.
} 


$$
\rho_{t, t+1}=\tau_{0}+\tau_{1} M K T_{t+1}+\tau_{2} S M B_{t+1}+\tau_{3} H M L_{t+1}
$$

where $\tau_{i}$ is a parameter, $M K T$ is the return on the market portfolio, $S M B$ is the return on a portfolio that is long small firms and short large firms, and $H M L$ is the return on a portfolio that is long high book-to-market firms and short low book-to-market firms.

As for the specification for the shadow cost, $\lambda_{i, t+1}$, we start with a parameterization consisting of nine firm- and industry-level financial variables specified in Whited and Wu (2006) and a measure for the insider ownership structure as an additional parameter:

$$
\begin{aligned}
\lambda_{i, t+1} & =\beta_{0}+\beta_{1}(\text { industry sales growth })_{i, t+1}+\beta_{2}(\text { firm sales growth })_{i, t+1}+\beta_{3} \log (\text { assets })_{i, t+1} \\
& +\beta_{4}(\text { cash flow/assets })_{i, t+1}+\beta_{5}(\text { industry debt/assets })_{i, t+1} \\
& +\beta_{6}(\text { long-term debt/assets })_{i, t+1}+\beta_{7}(\text { liquid assets/total assets })_{i, t+1} \\
& +\beta_{8}(\text { cash dividend dummy })_{i, t+1}+\beta_{9}(\text { number of analysts following the firm })_{i, t+1} \\
& +\beta_{10}(\text { insider control-ownership divergence measure })_{i, t+1},
\end{aligned}
$$

where $\beta_{i}$ is a parameter to be estimated.

We apply the nonlinear GMM estimator to Eq. (8) in its first differences to eliminate possible fixed firm effects. ${ }^{7}$ Following Whited and Wu (2006), we conduct the Holtz-Eakin (1988) test to test for the presence of firm fixed effects. The test strongly rejects the null hypothesis (at the 1\% significance level) that a non-differenced specification is correct.

Our instruments include all the variables in the Euler equation, as well as inventories, depreciation, current assets, current liabilities, the net value of capital stock, and tax payments, as suggested by Whited and Wu (2006). ${ }^{8}$ All of these instruments are normalized by total assets and lagged two periods in the GMM estimation.

${ }^{7}$ Additional instruments include three good predictors of profitability (Fama and French, 2000; Whited and $\mathrm{Wu}, 2006)$. They are the ratio of dividends to total assets, the average profitability over the previous three years, and a dummy if the net profit was positive in time $t$-1. We include year dummies in our estimation. Following Whited and Wu (2006), we impose two constraints on our GMM estimation. First, the expected value of the stochastic discount factor must equal $1 /\left(1+r_{f}\right)$, where $r_{f}$ is the risk-free rate. Second, the expectation of the shadow cost must be nonnegative. instruments.

${ }^{8}$ We conduct $F$-tests to verify instrument strength, and the $F$-statistics confirm the relevance of these 
Finally, to illustrate more intuitively how investment Euler equations work and how finance constraints operate in this setting, we present a simplified linear version of the Euler equation to explain its main mechanism. An Euler equation in a frictionless setting can be approximately expressed as follows (e.g., Bond and Meghir, 1994):

$$
\text { Investment } \left._{i t} \approx \beta_{1} \text { Investment }_{i, t+1}+\beta_{2} \text { (Marginal product of capital }\right)_{i, t+1}+\varepsilon_{i, t+1} \text {. }
$$

Therefore, Euler equations are roughly the first differences of investment- $q$ regressions, as the marginal product of capital is approximately the difference between $q$ and lagged $q$. Euler equations are thus very similar to the standard investment- $q$ regressions, but the Euler equation approach does not require measurement of the unobservable $q$, which is an appealing feature. In such a setting, a constrained firm invests too little today relative to tomorrow, given the realization of the marginal product of capital:

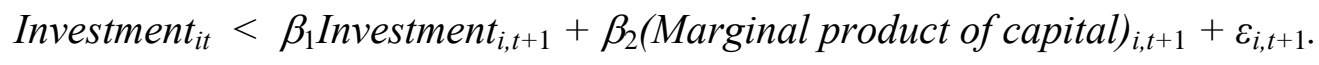

In this case, adding financial variables is roughly equivalent to adding interaction terms that downweight one side of the investment Euler equation via the relative shadow cost of external finance.

\section{Data}

\subsection{Sample construction}

We construct our sample from all firms included in the Compustat Industrial Annual files. Data on the divergence between insider cash-flow rights and controls rights are assembled from Gompers et al. (2010). ${ }^{9}$ Because this insider ownership data set covers the period from 1994 to 2002, we use the same time period as our sample period. This implies that the sample period

\footnotetext{
${ }^{9}$ We thank Paul Gompers, Joy Ishii, and Andrew Metrick for making the data available to us.
} 
actually used for our empirical analysis runs from 1997 to 2002 since we perform the nonlinear GMM estimation in first differences with twice lagged instruments.

We collect from Compustat all the firm-level data items required for estimating financial constraints as modeled in the previous section. Data on the number of analysts following the firm and on financial restatements are obtained from the Thomson Reuters Institutional Brokers’ Estimate System (I/B/E/S) and from the Financial Restatement Database collected by the U.S. Government Accountability Office (GAO), respectively. We delete any firm-year observations with missing data, and exclude from our sample all firms that are in the financial industry (Standard Industry Classification (SIC) codes 6000-6999) or the regulated utility industry (SIC codes 4900-4999). Our final sample consists of 25,377 firm-year observations.

\subsection{Variable definitions}

\subsubsection{Insider ownership structure}

Our proxies for the insider cash-flow rights and control rights are constructed using the insider ownership data set of Gompers et al. (2010). The data set contains information on dividends per share, the number of votes per share, the number of shares outstanding, and the total number of shares owned by corporate insiders including officers and directors for each class of stock at multiclass firms in the U.S. We then calculate the insider cash-flow rights and control rights at these firms as the total percentage of dividends and the total percentage of votes owned by the insiders across classes, respectively. ${ }^{10}$ For single-class firms, the insider cash-flow rights and control rights are equal by definition.

We use three measures to capture the deviation between insider control rights and insider cash-flow rights. The first measure, Divergence, is a dummy variable that takes the value of one

\footnotetext{
${ }^{10}$ Following Gompers et al. (2010), we assume that cash-flow rights are equal across classes if the dividend data do not exist.
} 
if insider control rights exceed insider cash-flow rights and zero otherwise. The second measure, the Control-ownership wedge, is defined as the difference between the control rights and cashflow rights held by insiders. The third measure is defined as the ratio of the insider control rights and cash-flow rights (Control-to-ownership ratio). ${ }^{11}$

\subsubsection{Other Euler equation variables and instruments}

Our specification for the Euler equation estimation includes a rich set of firm-level and industry-level variables, in addition to the measure for insider ownership structure, in order to capture all the observable firm characteristics and factors that influence the shadow cost of external finance. ${ }^{12}$ These variables include firm size (log total assets), profitability (the cash flow-to-assets ratio), cash holdings (the liquid assets-to-assets ratio), and dividend paying status (the cash dividend dummy), as well as firm and industry investment opportunities (firm and industry sales growth) and firm and industry leverage (firm and industry debt-to-assets ratios). Analyst coverage is included as a proxy for asymmetric information. The twice lagged instruments used in the GMM estimation include all the Euler-equation variables. Following Whited and $\mathrm{Wu}$ (2006), we also use as lagged instruments inventories, depreciation, current assets, the net value of capital stock, current liabilities, and tax payments, all of which are deflated by total assets.

The detailed definitions for these variables as well as all the other variables used in the paper are provided in Table 1. Table 2 provides summary statistics for the entire sample.

[Insert Tables 1 and 2 here]

\subsection{Univariate analyses}

${ }^{11}$ These definitions are standard in the ownership structure literature. See, for example, La Porta et al. (1999) and Claessens et al. (2000), among others.

\footnotetext{
${ }^{12}$ We construct these variables based on the definitions in Whited and Wu (2006).
} 
Before conducting the formal Euler equation structural analysis in the next section, we first take an initial look at some simple split-sample summary statistics to see if there are any broad patterns in the data that are consistent with our main hypothesis on the relationship between insiders' control-ownership divergence and firms' financing constraints. Specifically, we split the sample into groups with and without insider control-ownership divergence and compare the mean values of a variety of financial variables. This kind of analysis is analogous to the more traditional approach to indentify financially constrained firms, which sorts firms by firm characteristics that are believed to be associated with external finance constraints. The summary statistics for these two groups of firms are presented in Panel A of Table 3.

[Insert Table 3 here]

As can be seen from the table, the results are somewhat mixed. For instance, we find that firms with insider control-ownership divergence, on average, tend to have lower investment, lower cash flows, lower dividend payout ratios, and lower sales growth than firms without the control-ownership divergence. All these differences are statistically significant at the $5 \%$ level or better. These results suggest that firms with excess insider control rights appear to be more financially constrained than the others. However, we also find that firms with insider controlownership divergence, on average, tend to be larger in size, consistent with the pattern shown in Gompers et al. (2010). One possible explanation for this difference is that complex ownership structures such as multiple-class shares are more likely to appear in larger firms. Therefore, firm size in this case might be a proxy for ownership complexity rather than financing constraints. In addition, firms with excess insider control rights have more debt and are followed by slightly more analysts than firms without such divergence. These differences, however, might be driven simply by firm size since larger firms tend to have higher debt-to-assets ratios and more analyst coverage.

This simple split-sample comparison analysis shows the potential bias and risk in using the traditional approach to indentify financially constrained firms, which sorts firms by firm- 
specific characteristics that are believed to be associated with difficult access to external finance. The financial variables by themselves are not direct measures of financing constraints. As can be seen from the above analysis, sorting by different variables (e.g., cash flows versus size) can result in opposite interpretations. This highlights the importance and advantage of using the structural index approach (Whited and $\mathrm{Wu}, 2006$ ) to identify financial constraints, which is achieved via GMM estimation of an investment Euler equation augmented to account for financial frictions and encompass multiple factors that might affect financing constraints simultaneously into the model. Furthermore, using the structural approach allows us to clearly identify and examine the direct impact of the insider control-ownership divergence on external finance constraints rather than the indirect impact through other factors, while avoiding the common estimation problems such as simultaneity that plague reduced-form analyses. Therefore, in the next section, we take a structural approach and explore the relationship between the insider control-ownership divergence and external finance constraints by estimating the Euler equation of a standard intertemporal investment model augmented to account for financial constraints.

About 6\% of our firm-year observations are categorized as having insider controlownership divergence. One might wonder just how many firms have an insider controlownership wedge that is large enough to make a difference, especially in a developed country like the United States. An in-depth look at our sample reveals that out of 273 dual-class sample firms in the U.S., 154 have an insider control-ownership wedge that is greater than 0.20 , which is generally considered to be a significant divergence between control rights and cash-flow rights even among developing countries where excess control is a serious problem (Claessens et al., 2000). These high-wedge firms cover a variety of industries and include large S\&P 500 firms such as Ford Motor Co. and Adolph Coors Co. as well as smaller firms such as American Biogenetic Sciences Inc. Indeed, anecdotal evidence also suggests that the potential expropriation of other investors by insiders such as founding families, who retain their controls 
through the dual-class share structure, can have a significant impact on firm value and firm outcomes, even in the U.S. ${ }^{13}$

Finally, we explore the differences in the cost of equity and the cost of debt financing between firms with and without insider control-ownership divergence in order to get a more direct sense on whether the control-ownership divergence seems to be associated with costly external finance. Panel B of Table 3 reports these results.

First, we examine the cost of bank loans. We obtain the loan pricing data for our sample firms from the DealScan database, which covers detailed information on private loans to U.S. and foreign corporations since 1986. The cost of bank loans is measured by Loan spread, which is the interest rate spread over the London Interbank Offered Rate (LIBOR) or LIBOR equivalent on a loan plus associated loan origination fees (in basis points). Thus, it is an all-inclusive measure of loan price. As can be seen from Panel B of Table 3, the average loan spread for firms with insider control-ownership divergence is approximately 23 basis points higher than that for firms without such divergence even though firms with the control-ownership divergence are relatively larger firms. The difference is statistically significant at the $1 \%$ level.

Second, we examine the cost of public debt. We collect our sample of debt issues from the Mergent Fixed Investment Securities Database (FISD), which contains detailed information on public debt issues since 1980. Following the literature (e.g., Qiu and Yu, 2009), the cost of public debt, Credit spread, is defined as the difference, in basis points, between a corporate bond's yield to maturity and a linearly interpolated Treasury bond yield of identical maturity. ${ }^{14}$ The average credit spread for firms with insider control-ownership divergence is 42 basis points higher than that for firms without the divergence. The difference is both statistically significant (at the 1\% level) and economically significant (about 20\% of the sample average credit spread).

\footnotetext{
${ }^{13}$ For example, see the recent case on a U.S. dual-class company, Adelphia Communications Corporation's bankruptcy, the eleventh-largest bankruptcy case in history, described in Gilson and Villalonga (2009).

${ }^{14}$ Following Qiu and Yu (2009), we interpolate the one-year, three-year, five-year, seven-year, ten-year, and 30-year constant maturity Treasury yields, obtained from the Federal Reserve's Release (H15), into a piecewise linear term structure.
} 
In addition, we examine the cost of equity. Following Dong et al. (2006), we calculate the annualized cost of equity based on the Capital Asset Pricing Model (CAPM) using the market risk premium calculated as the average annual premium of the Center for Research in Security Prices (CRSP) value-weighted index over the risk-free rate over the preceding 30 years. ${ }^{15}$ These estimates also indicate that firms with insider control-ownership divergence are subject to higher financing costs. As can be seen from Panel B of Table 3, the average cost of equity for firms with insider excess control rights is significantly higher than that for the other firms.

Together, the ancillary evidence above suggests that insider ownership structure indeed appears to impact the cost of external finance. In the next section, we formally investigate the relationship between insider excess control rights and external finance constraints using the investment Euler-equation estimation.

\section{Results}

\subsection{Ownership structure and financial constraints}

\subsubsection{Euler-equation estimates}

In this section, we investigate whether a firm's insider ownership structure affects its external finance constraints by estimating the Euler equation for the model given by Eq. (8). Our parameterization of the shadow cost of external finance, $\lambda_{i, t+1}$, is specified in Eq. (10), using the original nine financial variables in Whited and Wu (2006) plus a measure for the insider controlownership divergence.

\footnotetext{
${ }^{15}$ Extreme estimates of the CAPM cost of equity (outside the range of 300-3,000 basis points, which are less than $1 \%$ of our sample) are winsorized.
} 
Table 4 reports the Euler-equation estimation results. In Panel A (columns 1 through 4), insider excess control is measured by Divergence, which is a dummy variable that takes the value of one if insider control rights exceed insider cash-flow rights and zero otherwise. In Panel B (columns 5 through 8) and Panel C (columns 9 through 12), the measures to capture the deviation between insider control rights and cash-flow rights are Control-ownership wedge and Control-to-ownership ratio, respectively.

[Insert Table 4 here]

For each panel, we employ the following estimation procedure (Whited and $\mathrm{Wu}, 2006$ ). In the first column of each panel, we start with the most general model, in which all ten variables in Eq. (10) are used to parameterize $\lambda_{i, t+1}$. The specification in each subsequent column drops the financial variable with the smallest $t$-value (i.e., the largest $p$-value) from the previous column. We perform two tests on model specification. ${ }^{16}$ The first is the $J$-test of overidentifying restrictions commonly utilized in GMM estimations to evaluate the suitability of the model (Hansen, 1982). Under the null hypothesis that the model is correctly specified and all the GMM assumptions hold, the test statistic is chi-squared distributed with degrees of freedom equal to the number of overidentifying restrictions. A rejection of the null hypothesis produced by the $J$-test implies that the model is misspecified and/or that the instruments do not satisfy the required orthogonality conditions (e.g., the instruments are not truly exogenous and thus, are invalid). The second is the $L$-test of exclusion restrictions in Whited and $\mathrm{Wu}$ (2006). In essence, the $L$ test assesses whether a variable or a set of variables belong in the Euler equation by comparing the minimized GMM objective functions for the most general and for a more parsimonious model (using the same set of instrumental variables and therefore having the same weighting matrices in the GMM objective functions), the difference of which is distributed as chi-squared with degrees of freedom equal to the number of excluded variables. A small $p$-value from the $L$ -

\footnotetext{
${ }^{16}$ See Whited and Wu (2006) for detailed discussions on the test statistics and their underlying distribution assumptions.
} 
test indicates that the omitted variables belong to the Euler equation and should not have been excluded from the model.

In the first three columns of Panel $\mathrm{A}$ in Table 4, the $J$-test does not produce a rejection of the exclusion restrictions, indicating that these models are not misspecified despite the deterministic specification of Eq. (8). In the fourth column, where we drop the firm sales growth, the model rejects the exclusion restrictions. The $p$-value of the $L$-test in column 4 also indicates that the omitted financial variables are jointly significant. Therefore, column 3 contains our final specification for the shadow cost of external funds, $\lambda_{i, t+1}$. Similarly, when we use the different measures for insider ownership structure in Panel B and Panel C of Table 4, we reach the same final specifications, in column 7 and column 11, respectively. Our final specification for $\lambda_{i, t+1}$, therefore, includes the log of assets, the cash flow-to-assets ratio, the debt-to-assets ratio, the dividend payment dummy, firm sales growth, industry sales growth, the number of analysts following the firm, and the measure for insider ownership structure:

$$
\begin{aligned}
\lambda_{i, t+1}= & \beta_{0}+\beta_{1}(\text { industry sales growth })_{i, t+1}+\beta_{2}(\text { firm sales growth })_{i, t+1} \\
& \left.+\beta_{3}(\text { log(assets })\right)_{i, t+1}+\beta_{4}(\text { cash flow/assets })_{i, t+1}+\beta_{5}(\text { long-term debt/assets })_{i, t+1} \\
& +\beta_{6}(\text { cash dividend dummy })_{i, t+1}+\beta_{7}(\text { (number of analysts following the firm })_{i, t+1} \\
& +\beta_{8}(\text { insider control-ownership divergence measure })_{i, t+1} .
\end{aligned}
$$

\subsubsection{Discussion}

The first thing to note from the Euler-equation estimation results in Table 4 is that our final specification and estimates are largely consistent with the Whited-Wu financial constraints index (Whited and Wu, 2006). A firm will have a higher shadow value of external funds, or in other words, be more financially constrained, if it is smaller in size, has lower cash flow, lower sales growth or higher leverage, belongs to a high growth industry, or does not pay dividends. The adjustment cost parameter is positive and significant, and the mark-up is significant and greater than one. The only slight difference is that our final model includes the number of 
analysts, which enters with a significantly negative sign. This variable is dropped in the last round of model selection in Whited and Wu (2006), but it does have the same sign and significance, indicating that firms with asymmetric information problems are associated with difficult access to external finance. For our sample firms and sample period, our estimation results indicate that the number of analysts should be included in the model. This underlines the importance of ensuring parameter stability across firms and over time in non-experimental sample estimates as highlighted in Whited and Wu (2006).

More importantly, the final specification for the shadow cost of external funds obtained from the estimation includes the measure for insider ownership structure. Compared to the other indicators of possible financial constraints previously identified in the literature, our results suggest that insider ownership structure is also an important factor that impacts firm financial constraints. The coefficients on all three measures of insider ownership structure are positive and statistically significant at the $1 \%$ level. A larger divergence between insider control rights and cash-flow rights is associated with a higher shadow cost of external funds; that is, firms whose insiders have large excess control rights will be more financially constrained. The effect of insider ownership structure on external finance constraints is also economically significant. Specifically, the estimates in column 3 of Table 4 suggest that the existence of a divergence between insider control rights and cash-flow rights is associated with an increase of 12.7 percentage points in the shadow cost of external funds. Similarly, a one-standard-deviation increase in the Control-ownership wedge or in the Control-to-ownership ratio increases the shadow cost of external funds by approximately 13 percentage points. These effects are quite substantial given that the mean estimated shadow cost of external funds is about $52 \%$.

Finally, following Whited and Wu (2006), we construct a financial constraints index based on our Euler-equation estimates and sort our sample firms by the index to evaluate how well our estimation captures firm financial constraints. The idea is to see whether firms categorized as financially constrained by our estimation demonstrate characteristics that would indicate difficult access to external finance. Specifically, the time $t$ value of the index is 
constructed based on the estimates from column 7 of Table 4, using the Control-ownership wedge to measure the insider excess control rights: ${ }^{17}$

$$
\begin{aligned}
& \text { 0.912(Control-ownership wedge) }{ }_{i t}-0.102 \text { (Cash flow/assets) }{ }_{i t} \\
& -0.043(\text { Cash dividend dummy })_{i t}+0.037(\text { Debt/assets })_{i t}-0.063(\text { Log assets })_{i t} \\
& -0.019\left(\text { Analyst coverage }_{i t}+0.134\left(\text { Industry sales growth) }{ }_{i t}\right.\right. \\
& -0.085 \text { (Firm sales growth) } i \text {. }
\end{aligned}
$$

We categorize our sample firms into three groups, from Least constrained to Most constrained, according to the financial constraints index. We report the mean values of various firm characteristics, including all the variables in our index as well as firm investment and measures for the insider ownership structure, for each group in Table 5.

[Insert Table 5 here]

The results in Table 5 indicate that estimates from our model perform well in capturing external finance constraints. The firms that are categorized as most constrained by our index exhibit characteristics that are consistent with the existence of financial constraints as shown in the literature (e.g., Whited and Wu, 2006). For example, they are smaller in size and have less analyst coverage and lower cash flows, sales growth, and dividend payments. The level of investment drops by $17 \%$ as the level of financial constraints increases. More importantly, notice that the most constrained firms also differ significantly from the least constrained firms in terms of ownership structure. There is a positive relationship between the level of financial constraints and all measures of the insider control-ownership divergence.

Overall, our results from the Euler-equation estimation indicate that insider ownership structure is an important factor that influences external finance constraints, and its effect remains strong and significant after controlling for a series of firm financial characteristics shown in the existing literature to affect firm financial constraints. The relationship between insider ownership structure and external finance constraints is consistent with the hypothesis that insider

\footnotetext{
${ }^{17}$ Using the other two measures of insider excess control rights to construct the index produces qualitatively similar results.
} 
excess control rights increase the likelihood of insider expropriation of the other shareholders and creditors and therefore intensify external financial constraints.

\subsection{Factors influencing the link between insider control-ownership divergence and financial constraints}

In this section, we investigate the factors that influence the relationship between insider ownership structure and external finance constraints. Our goal is to understand in what situations the divergence between insider control rights and cash-flow rights most severely affects the cost of external finance and increases financial constraints and, in turn, shed light on how such effects might be mitigated. We examine the following set of factors: firm informational opacity, financial restatement and misreporting, and institutional ownership. We implement the empirical estimation by including these factors and their interactions with the measure for insider ownership structure in the specification for $\lambda_{i, t+1}$ and re-estimating the Euler equation. ${ }^{18}$ We use Control-ownership wedge and Control-to-ownership ratio as our measures for insider control-ownership divergence. We expect that the effect of the insider controlownership divergence on external finance constraints should be more pronounced in situations where insiders with excess control rights are more likely to engage in self-dealing or expropriation activities. Analyses based on sample splits instead of interaction terms produce qualitatively similar and robust results (unreported but available upon request).

\subsubsection{Firm informational opacity}

${ }^{18}$ Following the original estimation methodology, we also include all the associated twice lagged instruments. 
Firm informational opacity makes monitoring by outside investors more difficult and therefore lowers the marginal costs to corporate insiders of engaging in self-dealing or expropriation activities. We therefore expect to find a stronger link between the insider controlownership divergence and external financial constraints in firms with greater informational opacity. Following previous studies (e.g., Lin et al., 2011), we use four widely used informational opacity measures in our analysis. The four measures are: (1) firm size measured by log of assets, (2) the number of analysts following the firm, (3) whether the firm has debt ratings, and (4) whether the firm is included in the S\&P 500 stock index. Intuitively, larger firms, firms with credit ratings, firms followed by more analysts, and firms included in the S\&P 500 index tend to be firms with lower degrees of informational opacity. To test our conjecture, we add each informational opacity measure and its interaction with the insider ownership structure to Eq. (13) and re-estimate the Euler equation using GMM estimation. The empirical results are presented in Table 6.

\section{[Insert Table 6 here]}

As can be seen from the table, larger firms, firms with credit ratings, firms followed by more analysts, and firms included in S\&P 500 are less financially constrained. This corroborates the evidence in Whited and Wu (2006) that financially constrained firms are associated with higher degrees of informational opacity. More interestingly, we find that firm informational opacity strengthens the link between the insider control-ownership divergence and external finance constraints, as indicated by the negative and statistically significant coefficient on the interaction terms between the insider control-ownership divergence and informational opacity measures across all model specifications. In columns 5 and 10, we include all four measures of informational opacity as well as their respective interaction terms with the insider ownership structure together in Eq. (13) and re-estimate the Euler equation. All coefficients on the interaction terms remain significantly negative. Out of the four measures, analyst coverage seems to have the most statistically and economically significant effect on the link between the insider excess control rights and firm financial constraints. For example, a one-standard- 
deviation increase in the number of analysts covering the firm reduces the impact of Controlownership wedge on the shadow cost of external funds by 0.297 . The $J$-test statistics indicate that these models including measures of informational opacity and their interactions with insider ownership structure are not misspecified. Overall, these results confirm our conjecture that the link between insider excess control rights and external finance constraints is stronger in firms with higher degrees of informational opacity.

\subsubsection{Financial restatement and misreporting}

Financial restatements change a firm's historical financial records, create uncertainty about the credibility of its financial reporting, and signal low quality of its information disclosure (Graham et al., 2008). As a result, investors may have serious concerns about other aspects of the firm's business operations and potential hidden actions. Such concerns can be particularly strong for firms with a divergence between insider control rights and cash-flow rights, where corporate insiders have the incentives and the ability to expropriate other investors. For these companies, financial restatements reflect negatively on current corporate insiders and can be viewed as symptomatic of larger issues of hidden self-dealing activities. We thus expect to find a stronger link between the insider control-ownership divergence and external finance constraints in firms with financial restatements. To test this, we add financial restatement dummy variables and their interactions with the divergence measure to Eq. (13) and re-estimate the Euler equation using GMM estimation.

Our restatement data are obtained from the Financial Restatement Database collected by the U.S. Government Accountability Office (GAO). For the time period from 1997 to 2002, the database contains more than 900 announced financial restatements. ${ }^{19}$ We construct a dummy variable Restatement, which takes on the value one if the firm has any historical financial

\footnotetext{
${ }^{19}$ The sample period used for estimation is therefore 2000 to 2002.
} 
restatement record in the database and zero otherwise. Furthermore, about half of the restatements are prompted by the U.S. Securities and Exchange Commission (SEC) or by external auditors. These cases are more likely to involve fraudulent misreporting. Following Graham et al. (2008), we treat these restatements as potentially fraudulent cases and construct a dummy variable Fraudulent restatement, which equals one if the firm has any historical fraudulent restatement record in the database and zero otherwise. We also interact these restatement indicators with the insider control-ownership divergence measures to see whether the effect of insider ownership structure on financial constraints is more prominent for the restating firms. The estimates for models including these dummy variables and their interaction terms with insider excess control rights are presented in Table 7.

[Insert Table 7 here]

The results in columns 1 and 3 of Table 7 indicate that firms with financial restatements in the past tend to have a higher shadow value of external finance and are therefore more financially constrained. Moreover, as expected, the link between the insider control-ownership wedge and external financial constraints is significantly stronger in firms with financial restatements. In columns 2 and 4, we further add the Fraudulent restatement dummy and its interaction term with insider excess control rights. Notice that since the Restatement dummy always equals one when the Fraudulent restatement dummy equals one, the coefficients on Fraudulent restatement and its interaction term capture the incremental effects of fraudulent misreporting over other types of restatements. The significantly positive estimates on the interaction terms of Fraudulent restatement and insider excess control rights indicate that the link between the insider control-ownership divergence and firm financial constraints is even stronger for firms involved in fraudulent misreporting. The $J$-test does not produce a rejection of the overidentifying restrictions in any model.

\subsubsection{Institutional ownership}


Institutional investors play an important monitoring function in corporate governance. Institutions are likely to be better-informed investors and have strong incentives and capabilities to devote resources to monitoring because of their large amounts of investment at stake (Shleifer and Vishny, 1997; Grinstein and Michaely, 2005). Furthermore, as fiduciaries who invest on behalf of others, institutional investors are disciplined by rules and regulations designed to mitigate agency conflicts (Grinstein and Michaely, 2005). As a result, the presence of institutional investors makes external monitoring more effective and thus increases the marginal costs to corporate insiders of engaging in expropriation or self-dealing activities. In this section, we investigate how institutional ownership influences firm financial constraints as well as its impact on the link between the insider control-ownership divergence and external finance constraints.

We examine two measures of institutional ownership. ${ }^{20}$ Our first measure, Institutional investor ownership, is computed as the number of shares held by all institutional investors divided by the total number of shares outstanding. The second measure, Institutional blockholder ownership, is calculated as the number of shares held by all institutional blockholders (defined as those who own at least $5 \%$ of outstanding shares) divided by the total number of shares outstanding. These measures are constructed from the Thomson Financial Institutional 13F Ownership database and have also been used in other recent studies (e.g., Qiu and $\mathrm{Yu}, 2009)$. To the extent that higher institutional ownership is associated with more activist shareholder monitoring and discipline on the management and thus indicates better governance and mitigations of agency issues, institutional ownership should help to alleviate firm financial constraints. In our Euler equation setting, this means that institutional ownership should have a negative effect on the shadow value of external finance. We investigate this relationship in Table 8 .

\section{[Insert Table 8 here]}

\footnotetext{
${ }^{20}$ Nikolov and Whited (2009) suggest that measures based on institutional ownership are less noisy proxies for governance than governance indices.
} 
In columns 1, 3, 5, and 7 of Table 8, we include the measure of institutional ownership in Eq. (13) and re-estimate the investment Euler equation using GMM estimation. The coefficients on Institutional investor ownership and Institutional blockholder ownership are indeed all negative and significant, suggesting that, everything else (including insider ownership structure) equal, firms with higher institutional ownership face lower external financial constraints.

Moreover, we investigate whether the effect of the insider control-ownership divergence on financial constraints is mitigated in firms with higher institutional ownership by further adding the interaction of institutional ownership and the insider control-ownership divergence to Eq. (13) and re-estimating the Euler equation. The intuition is that better corporate governance can have not only a direct effect on reducing external finance constraints but also an indirect effect through weakening the link between agency issues and financial constraints. The results from these estimations are reported in columns 2, 4, 6, and 8 of Table 8 . The estimates indicate that, as before, higher insider excess control rights and lower institutional ownership are associated with significantly higher firm financial constraints. More interestingly, we find that the effect of the insider control-ownership divergence on external finance constraints is less pronounced in firms with higher institutional ownership, as indicated by the significantly negative coefficients on the interaction terms across all specifications. Our results suggest that, conforming to the existing findings on the role of ownership and governance in alleviating agency problems, institutional ownership has a weakening effect on the positive link between insider excess control rights and firm financial constraints.

\section{Conclusion}

In this paper, we identify an important mechanism through which the insider controlownership divergence may affect firm values. Following the estimation strategy in Whited and $\mathrm{Wu}$ (2006), we examine the impact of the divergence between the control rights and cash-flow rights of corporate insiders on firms’ external finance constraints via GMM estimation of an 
investment Euler equation. Using a large sample of U.S. firms in the time period 1994 to 2002, we find that a wider divergence between insider control rights and cash-flow rights is associated with a significantly higher shadow value of external funds and therefore a higher degree of financial constraints. Moreover, we find that the effect of the insider control-ownership divergence on financial constraints is more pronounced for firms with higher levels of informational opacity as well as firms with financial restatements, especially those involved in fraudulent misreporting. In addition, we find that institutional ownership weakens the relationship between insider excess control rights and external finance constraints, indicating the monitoring role of institutional investors on potential expropriation activities of corporate insiders. Overall, our results imply that the insider control-ownership divergence increases the potential expropriation risks to outside investors and therefore intensifies external financing constraints. They also highlight the importance of insider ownership structure as a determinant of firms' external finance constraints and suggest that insider ownership structure can have a real impact on corporate financial outcomes. These insights help to better our understanding of the value implication of ownership structure and delineate the contexts in which the separation of ownership and control might be a more serious concern. 


\section{References}

Akerlof, G., Romer, P., 1993. Looting: The economic underworld of bankruptcy for profit. Brookings Papers on Economic Activity 2, 1-60.

Billett, M., Garfinkel, J., Jiang, Y., 2011. The influence of governance on investment: Evidence from a hazard model. Journal of Financial Economics, forthcoming.

Bond, S., Meghir, C., 1994. Dynamic investment models and the firm's financial policy. Review of Economic Studies 61, 197-222.

Claessens, S., Djankov, S., Lang, L., 2000. The separation of ownership and control in East Asian corporations. Journal of Financial Economics 58, 81-112.

Djankov, S., La Porta, R., López-de-Silanes, F., Shleifer, A., 2008. The law and economics of self-dealing. Journal of Financial Economics 88, 430-465.

Dong, M., Hirshleifer, D., Richardson, S., Teoh, S. H., 2006. Does investor misevaluation drive the takeover market? Journal of Finance 61, 725-762.

Erickson, T., Whited, T., 2000. Measurement error and the relationship between investment and q. Journal of Political Economy 108, 1027-1057.

Fama, E. F., French, K. R., 1993. Common risk factors in the returns on stocks and bonds. Journal of Financial Economics 33, 3-56.

Fama, E. F., French, K. R., 2000. Forecasting profitability and earnings. Journal of Business 73, 161-175.

Fazzari, S., Hubbard, R., Petersen, B., 1988. Financing constraints and corporate investment. Brookings Papers on Economic Activity 1, 141-206.

Friedman, E., Johnson, S., Mitton, T., 2003. Propping and tunneling. Journal of Comparative Economics 31, 732-750.

Gilson, S. C., Villalonga B., 2009. Adelphia Communications Corp.’s bankruptcy. Harvard Business School Case 208-071.

Gompers, P., Ishii, J., Metrick, A., 2010. Extreme governance: An analysis of dual-class firms in the United States. Review of Financial Studies 23, 1051-1088. 
Graham, J., Li, S., Qiu, J., 2008. Corporate misreporting and bank loan contracting. Journal of Financial Economics 89, 44-61.

Grinstein, Y., Michaely, R., 2005. Institutional holdings and payout policy. Journal of Finance 60, 1389-1426.

Hansen, L., 1982. Large sample properties of generalized method of moments estimators. Econometrica 50, 1029-1054.

Hennessy, C., Whited, T., 2007. How costly is external financing? Evidence from a structural estimation. Journal of Finance 62, 1705-1745.

Holtz-Eakin, D., 1988. Testing for individual effects in autoregressive models. Journal of Econometrics 39, 297-307.

Jensen, M., 1993. The modern industrial revolution, exit, and the failure of internal control systems. Journal of Finance 48, 831-880.

Jensen, M., Meckling, W., 1976. Theory of the firm: Managerial behavior, agency costs, and capital structure. Journal of Financial Economics 3, 305-360.

Johnson, S., La Porta, R., López-de-Silanes, F., Shleifer, A., 2000a. Tunneling. American Economic Review 90, 22-27.

Johnson, S., Boone, P., Breach, A., Friedman, E., 2000b. Corporate governance in the Asian financial crisis. Journal of Financial Economics 58, 141-186.

Kaplan, S., Zingales, L., 1997. Do financing constraints explain why investment is correlated with cash flow? Quarterly Journal of Economics 112, 169-216.

La Porta, R., López-de-Silanes, F., Shleifer, A., 1999. Corporate ownership around the world. Journal of Finance 54, 471-517.

La Porta, R., López-de-Silanes, F., Shleifer, A., Vishny, R., 2000. Investor protection and corporate governance. Journal of Financial Economics 58, 3-27.

La Porta, R., López-de-Silanes, F., Zamarripa, G., 2003. Related lending. Quarterly Journal of Economics 118, 231-268. 
Lin, C., Ma, Y., Malatesta P., Xuan, Y., 2011. Ownership structure and the cost of corporate borrowing. Journal of Financial Economics 100, 1-23.

Masulis R., Wang C., Xie, F., 2009. Agency cost at dual-class companies. Journal of Finance 64, 1697-1727.

Nikolov, B., Whited, T., 2009. Agency conflicts and cash: Estimates from a structural model. Unpublished working paper, University of Rochester.

Qiu, J., Yu, F., 2009. The market for corporate control and the cost of debt. Journal of Financial Economics 93, 505-524.

Shleifer, A., Vishny, R., 1997. A survey of corporate governance. Journal of Finance 52, 737783.

Stein, J.C., 2003. Agency, information and corporate investment. In: Constantinides, G.M., Harris, M., Stulz, R.M. (Eds.), Handbook of the Economics of Finance, Vol. 1A (Chapter 2). North-Holland, Amsterdam, pp. 111-165.

Whited, T., 1992. Debt, liquidity constraints, and corporate investment: Evidence from panel data. Journal of Finance 47, 1425-1460.

Whited, T., Wu, G., 2006. Financial constraints risk. Review of Financial Studies 19, 531-559. 
Table 1

Variable definitions

This table provides definitions for all the variables used in the paper.

\begin{tabular}{|c|c|}
\hline Variable & Definitions \\
\hline $\mathrm{I} / \mathrm{K}$ & $\begin{array}{l}\text { Investment divided by capital stock. Investment is capital } \\
\text { expenditure (CAPEX). Capital stock is the beginning period } \\
\text { capital, which equals net property, plant, and equipment minus } \\
\text { CAPEX plus depreciation and amortization. }\end{array}$ \\
\hline Cash flow/assets & $\begin{array}{l}\text { Cash flow divided by total assets. Cash flow is defined as income } \\
\text { plus depreciation and amortization. }\end{array}$ \\
\hline Cash dividend dummy & A dummy variable that equals one if the firm pays cash dividends \\
\hline Dividend payout ratio & Dividends divided by earnings \\
\hline Debt/assets & Long-term debt divided by total assets \\
\hline Log assets & Natural log of total assets \\
\hline Industrial sales growth & Three-digit SIC industry asset-weighted average sales growth rate \\
\hline Firm sales growth & Firm sales growth rate \\
\hline Analyst coverage & Number of analysts following the firm \\
\hline Cash/assets & $\begin{array}{l}\text { Liquid assets divided by total assets. Liquid assets are defined as } \\
\text { cash plus cash equivalents. }\end{array}$ \\
\hline Industry debt & $\begin{array}{l}\text { Three-digit SIC industry asset-weighted average long-term debt-to- } \\
\text { assets ratio }\end{array}$ \\
\hline MKT & Return on the market portfolio \\
\hline SMB & Return on a portfolio that is long small firms and short large firms \\
\hline HML & $\begin{array}{l}\text { Return on a portfolio that is long high book-to-market firms and } \\
\text { short low book-to-market firms }\end{array}$ \\
\hline Divergence dummy & $\begin{array}{l}\text { A dummy variable that equals one if insider control rights exceed } \\
\text { insider cash-flow rights }\end{array}$ \\
\hline Control-ownership wedge & Insider voting rights minus insider cash-flow rights \\
\hline Control-to-ownership ratio & Insider voting rights divided by insider cash-flow rights \\
\hline S\&P 500 dummy & $\begin{array}{l}\text { A dummy variable that equals one if the firm is in the S\&P } 500 \\
\text { stock index }\end{array}$ \\
\hline Credit rating dummy & $\begin{array}{l}\text { A dummy variable that equals one if the firm has an S\&P credit } \\
\text { rating }\end{array}$ \\
\hline Financial restatement dummy & $\begin{array}{l}\text { A dummy variable that equals one if the firm has a historical } \\
\text { financial restatement record in the U.S. Government Accountability } \\
\text { Office (GAO) database }\end{array}$ \\
\hline Fraudulent restatement dummy & $\begin{array}{l}\text { A dummy variable that equals one if the firm has historical } \\
\text { fraudulent financial restatements (prompted by the SEC or external } \\
\text { auditors) recorded in the GAO database }\end{array}$ \\
\hline Institutional investor ownership & $\begin{array}{l}\text { Number of shares held by all institutional investors divided by the } \\
\text { total number of shares outstanding }\end{array}$ \\
\hline Institutional blockholder ownership & $\begin{array}{l}\text { Number of shares held by all institutional blockholders (defined as } \\
\text { those who own at least } 5 \% \text { of outstanding shares) divided by the } \\
\text { total number of shares outstanding }\end{array}$ \\
\hline
\end{tabular}




\section{Table 2}

Summary statistics

This table presents the mean, standard deviation (STD), and number of observations $(N)$ for all the variables used in the paper. The sample period is 1994 to 2002. Definitions of all the variables are reported in Table 1.

\begin{tabular}{lccc}
\hline Variable & Mean & STD & $N$ \\
\hline I/K & 0.338 & 0.422 & 25,377 \\
Cash flow/assets & 0.128 & 0.294 & 25,377 \\
Cash dividend dummy & 0.302 & 0.459 & 25,377 \\
Dividend payout ratio & 0.132 & 0.475 & 25,377 \\
Debt/assets & 0.185 & 0.233 & 25,377 \\
Log assets & 4.493 & 2.972 & 25,377 \\
Industry sales growth & 0.059 & 0.140 & 25,377 \\
Firm sales growth & 0.086 & 0.389 & 25,377 \\
Analyst coverage & 2.490 & 3.164 & 25,377 \\
Cash/assets & 0.054 & 0.145 & 25,377 \\
Industry debt & 0.263 & 0.097 & 25,377 \\
MKT & 0.016 & 0.039 & 25,377 \\
SMB & 0.017 & 0.029 & 25,377 \\
HML & 0.002 & 0.047 & 25,377 \\
Divergence dummy & 0.059 & 0.236 & 25,377 \\
Control-ownership wedge & 0.013 & 0.142 & 25,377 \\
Control-to-ownership ratio & 1.050 & 0.386 & 25,377 \\
S\&P 500 dummy & 0.076 & 0.265 & 25,377 \\
Credit rating dummy & 0.248 & 0.432 & 25,377 \\
Financial restatement dummy & 0.041 & 0.198 & 19,154 \\
Fraudulent restatement dummy & 0.024 & 0.152 & 19,154 \\
Institutional investor ownership & 0.237 & 0.282 & 19,154 \\
Institutional blockholder ownership & 0.235 & 0.283 & 19,154 \\
\hline
\end{tabular}




\section{Table 3}

Control-ownership divergence, firm characteristics, and cost of financing

This table presents the mean values of a variety of financial variables (Panel A) and measures of cost of financing (Panel B) for the sample firms, distinguishing between firms with and without insider control-ownership divergence. The sample period is 1994 to 2002. Loan spread is the interest rate spread over LIBOR or LIBOR equivalent on a loan plus associated loan origination fees (in basis points). Credit spread is defined as the difference, in basis points, between a corporate bond's yield to maturity and a linearly interpolated Treasury bond yield of identical maturity. Cost of equity is estimated based on the Capital Asset Pricing Model (CAPM) using the market risk premium calculated as the average annual premium of the CRSP value-weighted index over the risk-free rate over the preceding 30 years. Definitions of all the other variables are reported in Table 1 . Significance at the $10 \%, 5 \%$, and $1 \%$ levels is indicated by *,**, and ***, respectively.

\begin{tabular}{|c|c|c|c|c|}
\hline Panel A & $(1)$ & (2) & \multicolumn{2}{|l|}{ (3) } \\
\hline Variable & Divergence $=1$ & Divergence $=0$ & \multicolumn{2}{|c|}{ Difference: (1) - (2) } \\
\hline $\mathrm{I} / \mathrm{K}$ & 0.261 & 0.343 & -0.082 & $\star \star *$ \\
\hline Cash flow/assets & 0.108 & 0.129 & -0.021 & $\star \star \star *$ \\
\hline Dividend payout ratio & 0.103 & 0.134 & -0.031 & ** \\
\hline Debt/assets & 0.199 & 0.184 & 0.015 & ** \\
\hline Log assets & 5.554 & 4.426 & 1.128 & $* \star *$ \\
\hline Firm sales growth & 0.066 & 0.088 & -0.022 & ** \\
\hline Analyst coverage & 2.633 & 2.481 & 0.152 & * \\
\hline Cash/assets & 0.032 & 0.055 & -0.023 & $\star \star \star$ \\
\hline Panel B & (1) & (2) & \multicolumn{2}{|l|}{ (3) } \\
\hline Variable & Divergence $=1$ & Divergence $=0$ & \multicolumn{2}{|c|}{ Difference: (1) - (2) } \\
\hline Loan spread (basis points) & 194.987 & 172.351 & 22.636 & $\star \star \star *$ \\
\hline Credit spread (basis points) & 258.748 & 217.170 & 41.578 & $\star \star *$ \\
\hline Cost of equity (\%) & 11.153 & 10.214 & 0.939 & $\star \star \star$ \\
\hline
\end{tabular}




\section{Table 4}

Insider control-ownership divergence and external finance constraints: Euler-equation estimates

This table presents the estimates from nonlinear GMM estimation of the investment Euler equation (Whited, 1992; Whited and Wu, 2006). The estimation is done on the model given by Eq. (8) in first differences with twice lagged instruments. The sample period used for estimation is 1997 to $2002 . \alpha_{2}$ and $\alpha_{3}$ are adjustment cost parameters, and $\mu$ is a mark-up. Divergence is a dummy variable that equals one if insider control rights exceed insider cash-flow rights and zero otherwise. Controlownership wedge is defined as the difference between insider control rights and cash-flow rights. Control-to-ownership ratio is defined as the ratio of insider control rights and cash-flow rights. Definitions of all the other variables are reported in Table 1 . The $p$-values for the coefficients are reported in brackets. The $p$-values of the $J$ test (test of overidentifying restrictions) and the $L$-test (test of variable exclusion restrictions) on model specification are reported in the last two rows. Significance at the $10 \%, 5 \%$, and $1 \%$ levels is indicated by $* * *$, and $* * *$, respectively.

\begin{tabular}{|c|c|c|c|c|c|c|c|c|c|c|c|c|}
\hline & \multicolumn{4}{|c|}{ Panel $A$} & \multicolumn{4}{|c|}{ Panel B } & \multicolumn{4}{|c|}{ Panel C } \\
\hline & $(1)$ & $(2)$ & $(3)$ & (4) & $(5)$ & $(6)$ & $(7)$ & $(8)$ & $(9)$ & $(10)$ & $(11)$ & $(12)$ \\
\hline \multirow[t]{2}{*}{$\alpha_{2}$} & 0.628 & 0.730 & 0.651 & 0.683 & 0.649 & 0.702 & 0.650 & 0.681 & 0.675 & 0.696 & 0.650 & 0.672 \\
\hline & {$[0.019]^{* *}$} & {$[0.015]^{* *}$} & {$[0.019]^{* *}$} & {$[0.017]^{* *}$} & {$[0.002]^{* * *}$} & {$[0.005]^{* * *}$} & {$[0.003]^{* * *}$} & {$[0.007]^{* * *}$} & {$[0.014]^{* *}$} & {$[0.017]^{* *}$} & {$[0.015]^{* *}$} & {$[0.016]^{* *}$} \\
\hline \multirow[t]{2}{*}{$\alpha_{3}$} & -0.417 & -0.504 & -0.463 & -0.484 & -0.429 & -0.503 & -0.463 & -0.484 & -0.432 & -0.497 & -0.462 & -0.476 \\
\hline & {$[0.032]^{* *}$} & {$[0.031]^{* *}$} & {$[0.033]^{* *}$} & {$[0.039]^{* *}$} & {$[0.018]^{* *}$} & {$[0.021]^{* *}$} & {$[0.019]^{* *}$} & {$[0.025]^{* *}$} & {$[0.018]^{* *}$} & {$[0.017]^{* *}$} & {$[0.021]^{* *}$} & {$[0.019]^{* *}$} \\
\hline \multirow[t]{2}{*}{ Mark-up $(\mu)$} & 1.074 & 0.986 & 1.057 & 0.972 & 1.105 & 0.973 & 1.069 & 1.002 & 1.069 & 1.011 & 1.061 & 1.026 \\
\hline & {$[0.027]^{* *}$} & {$[0.025]^{* *}$} & {$[0.024]^{* *}$} & {$[0.026]^{* *}$} & {$[0.027]^{* *}$} & {$[0.031]^{* *}$} & {$[0.028]^{* *}$} & {$[0.030]^{* *}$} & {$[0.025]^{* *}$} & {$[0.026]^{* *}$} & {$[0.021]^{* *}$} & {$[0.023]^{* *}$} \\
\hline \multirow[t]{2}{*}{ Divergence dummy } & 0.125 & 0.119 & 0.127 & 0.130 & & & & & & & & \\
\hline & {$[0.002]^{* * *}$} & {$[0.007]^{* * *}$} & {$[0.003]^{* * *}$} & {$[0.004]^{* * *}$} & & & & & & & & \\
\hline \multirow[t]{2}{*}{ Control-ownership wedge } & & & & & 0.761 & 0.885 & 0.912 & 0.947 & & & & \\
\hline & & & & & {$[0.002]^{* * *}$} & {$[0.009]^{* * *}$} & {$[0.004]^{* * *}$} & {$[0.005]^{* * *}$} & & & & \\
\hline \multirow[t]{2}{*}{ Control-to-ownership ratio } & & & & & & & & & 0.342 & 0.312 & 0.330 & 0.306 \\
\hline & & & & & & & & & {$[0.004]^{* * *}$} & {$[0.005]^{* * *}$} & {$[0.004]^{* * *}$} & {$[0.008]^{* * *}$} \\
\hline \multirow[t]{2}{*}{ Cash flow/assets } & -0.113 & -0.100 & -0.106 & -0.115 & -0.111 & -0.097 & -0.102 & -0.112 & -0.122 & -0.111 & -0.104 & -0.117 \\
\hline & {$[0.019]^{* *}$} & {$[0.018]^{* *}$} & {$[0.017]^{* *}$} & {$[0.015]^{* *}$} & {$[0.024]^{* *}$} & {$[0.026]^{* *}$} & {$[0.023]^{* *}$} & {$[0.021]^{* *}$} & {$[0.022]^{* *}$} & {$[0.020]^{* *}$} & {$[0.021]^{* *}$} & {$[0.016]^{* *}$} \\
\hline \multirow[t]{2}{*}{ Cash dividend dummy } & -0.038 & -0.046 & -0.041 & -0.043 & -0.040 & -0.045 & -0.043 & -0.048 & -0.044 & -0.048 & -0.044 & -0.050 \\
\hline & {$[0.066]^{*}$} & {$[0.039]^{* *}$} & {$[0.054]^{*}$} & {$[0.051]^{*}$} & {$[0.044]^{* *}$} & {$[0.071]^{*}$} & {$[0.116]$} & [0.109] & {$[0.034]^{* *}$} & {$[0.033]^{* *}$} & {$[0.035]^{* *}$} & {$[0.032]^{* *}$} \\
\hline \multirow[t]{2}{*}{ Debt/assets } & 0.045 & 0.046 & 0.043 & 0.049 & 0.039 & 0.042 & 0.037 & 0.040 & 0.031 & 0.035 & 0.030 & 0.034 \\
\hline & {$[0.032]^{* *}$} & {$[0.034]^{* *}$} & {$[0.037]^{* *}$} & {$[0.035]^{* *}$} & {$[0.061]^{*}$} & {$[0.039]^{* *}$} & {$[0.062]^{*}$} & {$[0.058]^{*}$} & [0.136] & {$[0.043]^{* *}$} & [0.136] & [0.128] \\
\hline
\end{tabular}

(continued on the next page) 
Table 4

Insider control-ownership divergence and external finance constraints: Euler equation estimates

(Continued)

\begin{tabular}{|c|c|c|c|c|c|c|c|c|c|c|c|c|}
\hline & \multicolumn{4}{|c|}{ Panel A } & \multicolumn{4}{|c|}{ Panel B } & \multicolumn{4}{|c|}{ Panel C } \\
\hline & $(1)$ & $(2)$ & (3) & (4) & (5) & (6) & $(7)$ & (8) & $(9)$ & $(10)$ & (11) & (12) \\
\hline \multirow[t]{2}{*}{ Log assets } & -0.052 & -0.047 & -0.052 & -0.055 & -0.069 & -0.057 & -0.063 & -0.067 & -0.072 & -0.052 & -0.057 & -0.051 \\
\hline & {$[0.078]^{*}$} & {$[0.077]^{*}$} & [0.069]* & {$[0.062]^{*}$} & {$[0.029]^{* *}$} & {$[0.033]^{* *}$} & {$[0.031]^{* *}$} & {$[0.028]^{* *}$} & {$[0.036]^{* *}$} & {$[0.074]^{*}$} & {$[0.071]^{*}$} & {$[0.064]^{*}$} \\
\hline \multirow[t]{2}{*}{ Analyst coverage } & -0.018 & -0.016 & -0.011 & -0.012 & -0.020 & -0.016 & -0.019 & -0.017 & -0.016 & -0.014 & -0.012 & -0.015 \\
\hline & {$[0.031]^{* *}$} & {$[0.032]^{* *}$} & {$[0.034]^{* *}$} & {$[0.037]^{* *}$} & {$[0.028]^{* *}$} & {$[0.025]^{* *}$} & {$[0.028]^{* *}$} & {$[0.031]^{* *}$} & {$[0.034]^{* *}$} & {$[0.051]^{*}$} & {$[0.057]^{*}$} & {$[0.062]^{*}$} \\
\hline \multirow[t]{2}{*}{ Industry sales growth } & 0.166 & 0.169 & 0.148 & 0.167 & 0.151 & 0.164 & 0.134 & & 0.145 & 0.171 & 0.132 & \\
\hline & {$[0.034]^{* *}$} & {$[0.031]^{* *}$} & {$[0.035]^{* *}$} & {$[0.031]^{* *}$} & {$[0.095]^{*}$} & {$[0.032]^{* *}$} & {$[0.120]$} & & {$[0.114]$} & {$[0.023]^{* *}$} & {$[0.141]$} & \\
\hline \multirow[t]{2}{*}{ Firm sales growth } & -0.072 & -0.080 & -0.071 & & -0.091 & -0.091 & -0.085 & -0.096 & -0.080 & -0.086 & -0.078 & -0.084 \\
\hline & [0.129] & {$[0.041]^{* *}$} & [0.127] & & {$[0.033]^{* *}$} & {$[0.053]^{*}$} & {$[0.032]^{* *}$} & {$[0.029]^{* *}$} & {$[0.063]^{*}$} & {$[0.038]^{* *}$} & {$[0.062]^{*}$} & {$[0.056]^{*}$} \\
\hline \multirow[t]{2}{*}{ Cash/assets } & -0.003 & -0.004 & & & -0.006 & -0.006 & & & -0.003 & -0.005 & & \\
\hline & [0.175] & [0.182] & & & [0.149] & [0.153] & & & {$[0.168]$} & [0.164] & & \\
\hline \multirow[t]{2}{*}{ Industry debt } & -0.037 & & & & -0.039 & & & & -0.041 & & & \\
\hline & [0.218] & & & & {$[0.206]$} & & & & [0.201] & & & \\
\hline \multirow[t]{2}{*}{ MKT } & -0.767 & -0.727 & -0.779 & -0.802 & -0.663 & -0.774 & -0.720 & -0.763 & -0.684 & -0.573 & -0.625 & -0.662 \\
\hline & {$[0.033]^{* *}$} & [0.102] & {$[0.036]^{* *}$} & {$[0.078]^{*}$} & [0.134] & {$[0.035]^{* *}$} & [0.133] & [0.122] & {$[0.034]^{* *}$} & [0.109] & [0.093]* & {$[0.079]^{*}$} \\
\hline \multirow[t]{2}{*}{ SMB } & 0.956 & 1.241 & 1.137 & 1.217 & 1.429 & 1.281 & 1.211 & 1.359 & 1.099 & 1.188 & 1.127 & 1.317 \\
\hline & {$[0.080]^{*}$} & {$[0.040]^{* *}$} & {$[0.096]^{*}$} & {$[0.068]^{*}$} & {$[0.049]^{* *}$} & {$[0.181]$} & {$[0.170]$} & {$[0.160]$} & [0.164] & [0.188] & [0.165] & {$[0.036]^{* *}$} \\
\hline \multirow[t]{2}{*}{ HML } & 1.226 & 1.064 & 1.174 & 1.272 & 1.164 & 1.259 & 1.163 & 1.056 & 1.003 & 0.851 & 1.053 & 0.979 \\
\hline & {$[0.036]^{* *}$} & [0.127] & {$[0.087]^{*}$} & {$[0.077]^{*}$} & {$[0.018]^{* *}$} & {$[0.020]^{* *}$} & {$[0.021]^{* *}$} & [0.124] & {$[0.097]^{*}$} & {$[0.037]^{* *}$} & {$[0.091]^{*}$} & [0.105] \\
\hline Number of observations & 19,154 & 19,154 & 19,154 & 19,154 & 19,154 & 19,154 & 19,154 & 19,154 & 19,154 & 19,154 & 19,154 & 19,154 \\
\hline Number of firms & 4,518 & 4,518 & 4,518 & 4,518 & 4,518 & 4,518 & 4,518 & 4,518 & 4,518 & 4,518 & 4,518 & 4,518 \\
\hline$p$-Value of $J$-test & 0.422 & 0.263 & 0.217 & $0.034^{* *}$ & 0.473 & 0.284 & 0.213 & $0.038^{* *}$ & 0.431 & 0.220 & 0.206 & $0.032 * *$ \\
\hline$p$-Value of $L$-test & & 0.431 & 0.220 & $0.043^{* *}$ & & 0.455 & 0.287 & $0.041^{* *}$ & & 0.497 & 0.269 & $0.040^{* *}$ \\
\hline
\end{tabular}


Table 5

Univariate analyses based on structural financial constraints index

This table presents the mean values of a variety of firm characteristics for sample firms sorted by a financial constraints index based on the Euler-equation estimates from column 7 of Table 4. Specifically, the time $t$ value of the index is constructed as 0.912(Control-ownership wedge) ${ }_{i t}-$ 0.102 (Cash flow/assets) $_{i t}-0.043$ (Cash dividend dummy) ${ }_{i t}+0.037(\text { Debt/assets })_{i t}-0.063\left(\right.$ Log assets) ${ }_{i t}-$ 0.019 (Analyst coverage) $_{i t}+0.134$ (Industry sales growth) ${ }_{i t}-0.085$ (Firm sales growth) ${ }_{i t}$. The sample period is 1994 to 2002. Definitions of all the other variables are reported in Table 1. Significance at the $10 \%, 5 \%$, and $1 \%$ levels is indicated by $*, * *$, and ${ }^{* * *}$, respectively.

\begin{tabular}{|c|c|c|c|c|c|}
\hline \multirow{5}{*}{$\begin{array}{l}\text { Variable } \\
\text { Divergence dummy }\end{array}$} & (1) & $(2)$ & (3) & \multicolumn{2}{|l|}{ (4) } \\
\hline & \multicolumn{3}{|c|}{ Structural financial constraints index } & \multirow{3}{*}{\multicolumn{2}{|c|}{$\begin{array}{c}\text { Difference } \\
\text { (3) - (1) }\end{array}$}} \\
\hline & \multirow{2}{*}{$\begin{array}{c}\text { Low } \\
\text { Least } \\
\text { constrained } \\
\end{array}$} & \multirow[t]{2}{*}{ Medium } & \multirow{2}{*}{$\begin{array}{c}\text { High } \\
\text { Most } \\
\text { constrained } \\
\end{array}$} & & \\
\hline & & & & & \\
\hline & 0.035 & 0.037 & 0.106 & 0.071 & *** \\
\hline Control-ownership wedge & 0.003 & 0.004 & 0.031 & 0.028 & *** \\
\hline Control-to-ownership ratio & 1.018 & 1.020 & 1.112 & 0.094 & 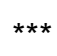 \\
\hline $\mathrm{I} / \mathrm{K}$ & 0.367 & 0.344 & 0.304 & -0.063 & *** \\
\hline Cash flow/assets & 0.173 & 0.111 & 0.099 & -0.074 & 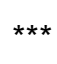 \\
\hline Cash dividend dummy & 0.586 & 0.239 & 0.080 & -0.506 & *** \\
\hline Debt/assets & 0.177 & 0.187 & 0.190 & 0.013 & *** \\
\hline Log assets & 7.033 & 4.577 & 1.870 & -5.163 & *** \\
\hline Industry sales growth & 0.048 & 0.058 & 0.072 & 0.024 & *** \\
\hline Firm sales growth & 0.139 & 0.110 & 0.010 & -0.129 & *** \\
\hline Analyst coverage & 5.335 & 1.345 & 0.790 & -4.545 & *** \\
\hline Structural financial constraints index & 0.277 & 0.576 & 0.742 & 0.465 & *夫* \\
\hline
\end{tabular}


Table 6

Firm information opacity and the effect of insider control-ownership divergence on external finance constraints

This table presents the estimates from nonlinear GMM estimation of the investment Euler equation (Whited, 1992; Whited and Wu, 2006). The estimation is done on the model given by Eq. (8) in first differences with twice lagged instruments. The sample period used for estimation is 1997 to $2002 . \alpha_{2}$ and $\alpha_{3}$ are adjustment cost parameters, and $\mu$ is a mark-up. Control-ownership wedge is defined as the difference between insider control rights and cash-flow rights. Control-to-ownership ratio is defined as the ratio of insider control rights and cash-flow rights. $S \& P 500$ is a dummy variable that equals one if the firm is in the S\&P 500 stock index. Credit rating dummy equals one if the firm has an S\&P credit rating. Definitions of all the other variables are reported in Table 1. The $p$-values for the coefficients are reported in brackets. The $p$-values of the $J$-test (test of overidentifying restrictions) on model specification are reported in the last row. Significance at the $10 \%, 5 \%$, and $1 \%$ levels is indicated by ${ }^{*},{ }^{* *}$, and ${ }^{* * *}$, respectively.

\begin{tabular}{|c|c|c|c|c|c|c|c|c|c|c|}
\hline & (1) & (2) & (3) & (4) & (5) & (6) & (7) & (8) & (9) & (10) \\
\hline \multirow[t]{2}{*}{$\alpha_{2}$} & 0.649 & 0.634 & 0.772 & 0.648 & 0.624 & 0.651 & 0.626 & 0.780 & 0.651 & 0.625 \\
\hline & {$[0.021]^{* *}$} & {$[0.014]^{* *}$} & {$[0.008]^{* *}$} & {$[0.004]^{* * *}$} & {$[0.025]^{* *}$} & {$[0.019]^{* *}$} & {$[0.024]^{* *}$} & {$[0.021]^{* *}$} & {$[0.012]^{* *}$} & {$[0.027]^{* *}$} \\
\hline \multirow[t]{2}{*}{$\alpha_{3}$} & -0.463 & -0.454 & -0.531 & -0.462 & -0.438 & -0.462 & -0.493 & -0.532 & -0.463 & -0.431 \\
\hline & {$[0.026]^{* *}$} & {$[0.046]^{* *}$} & {$[0.082] *$} & {$[0.069]^{*}$} & {$[0.071] *$} & [0.123] & {$[0.141]$} & {$[0.041]^{* *}$} & {$[0.015]^{* *}$} & {$[0.117]$} \\
\hline \multirow[t]{2}{*}{ Mark-up $(\mu)$} & 1.068 & 1.069 & 1.070 & 1.069 & 1.043 & 1.063 & 1.076 & 1.071 & 1.060 & 1.041 \\
\hline & {$[0.047]^{* *}$} & {$[0.036]^{* *}$} & {$[0.016]^{* *}$} & {$[0.042]^{* *}$} & {$[0.046]^{* *}$} & {$[0.008]^{* * *}$} & {$[0.012]^{* *}$} & {$[0.029]^{* *}$} & {$[0.011]^{* *}$} & {$[0.016]^{* *}$} \\
\hline \multirow[t]{2}{*}{ Control-ownership wedge (Wedge) } & 0.912 & 0.922 & 0.917 & 0.916 & 0.841 & & & & & \\
\hline & {$[0.007] * * *$} & {$[0.003]^{* * *}$} & {$[0.016]^{* *}$} & {$[0.002]^{* * *}$} & {$[0.008] * * *$} & & & & & \\
\hline \multirow[t]{2}{*}{ Control-to-ownership ratio (Ratio) } & & & & & & 0.342 & 0.315 & 0.332 & 0.346 & 0.221 \\
\hline & & & & & & {$[0.002]^{* * *}$} & {$[0.011]^{* *}$} & {$[0.002]^{* * *}$} & {$[0.005]^{* * *}$} & {$[0.005]^{* * *}$} \\
\hline \multirow[t]{2}{*}{ Wedge $x$ Log assets } & -0.116 & & & & -0.104 & & & & & \\
\hline & {$[0.027]^{* *}$} & & & & {$[0.062]^{*}$} & & & & & \\
\hline \multirow[t]{2}{*}{ Wedge x Analyst coverage } & & -0.102 & & & -0.094 & & & & & \\
\hline & & {$[0.031]^{* *}$} & & & {$[0.003] * * *$} & & & & & \\
\hline \multirow[t]{2}{*}{ Wedge x S\&P500 } & & & -0.391 & & -0.287 & & & & & \\
\hline & & & {$[0.000]^{* * *}$} & & {$[0.042]^{* *}$} & & & & & \\
\hline \multirow[t]{2}{*}{ Wedge x Credit rating dummy } & & & & -0.519 & -0.437 & & & & & \\
\hline & & & & {$[0.000]^{* * *}$} & {$[0.012]^{* *}$} & & & & & \\
\hline \multirow[t]{2}{*}{ Ratio x Log assets } & & & & & & -0.036 & & & & -0.024 \\
\hline & & & & & & {$[0.014]^{* *}$} & & & & {$[0.073]^{*}$} \\
\hline \multirow[t]{2}{*}{ Ratio x Analyst coverage } & & & & & & & -0.035 & & & -0.031 \\
\hline & & & & & & & {$[0.016]^{* *}$} & & & {$[0.006]^{* * *}$} \\
\hline \multirow[t]{2}{*}{ Ratio x S\&P500 } & & & & & & & & -0.138 & & -0.127 \\
\hline & & & & & & & & {$[0.011]^{* *}$} & & {$[0.039]^{* *}$} \\
\hline \multirow[t]{2}{*}{ Ratio x Credit rating dummy } & & & & & & & & & -0.259 & -0.231 \\
\hline & & & & & & & & & {$[0.027]^{* *}$} & {$[0.015]^{* *}$} \\
\hline
\end{tabular}

(continued on the next page) 
Table 6

Firm information opacity and the effect of insider control-ownership divergence on external finance constraints (Continued)

\begin{tabular}{|c|c|c|c|c|c|c|c|c|c|c|}
\hline & $(1)$ & $(2)$ & $(3)$ & (4) & $(5)$ & (6) & $(7)$ & $(8)$ & (9) & $(10)$ \\
\hline \multirow[t]{2}{*}{ S\&P500 } & & & -0.127 & & -0.121 & & & -0.026 & & -0.020 \\
\hline & & & {$[0.001]^{* * *}$} & & {$[0.017]^{* *}$} & & & {$[0.000]^{* * *}$} & & {$[0.014]^{* *}$} \\
\hline \multirow[t]{2}{*}{ Credit rating dummy } & & & & -0.041 & -0.036 & & & & -0.035 & -0.031 \\
\hline & & & & {$[0.023]^{* *}$} & {$[0.028]^{* *}$} & & & & {$[0.017]^{* *}$} & {$[0.026]^{* *}$} \\
\hline \multirow[t]{2}{*}{ Log assets } & -0.059 & -0.065 & -0.061 & -0.062 & -0.056 & -0.059 & -0.052 & -0.061 & -0.063 & -0.053 \\
\hline & {$[0.080]^{*}$} & {$[0.143]$} & {$[0.027]^{* *}$} & {$[0.022]^{* *}$} & {$[0.088]^{*}$} & {$[0.151]$} & {$[0.028]^{* *}$} & {$[0.096]^{*}$} & {$[0.178]$} & {$[0.162]$} \\
\hline \multirow[t]{2}{*}{ Analyst coverage } & -0.019 & -0.018 & -0.014 & -0.019 & -0.016 & -0.019 & -0.014 & -0.015 & -0.018 & -0.021 \\
\hline & {$[0.017]^{* *}$} & {$[0.084]^{*}$} & {$[0.011]^{* *}$} & {$[0.070]^{*}$} & {$[0.024]^{* *}$} & {$[0.018]^{* *}$} & {$[0.051]^{*}$} & {$[0.079]^{*}$} & {$[0.036]^{* *}$} & {$[0.016]^{* *}$} \\
\hline \multirow[t]{2}{*}{ Cash flow/assets } & -0.103 & -0.104 & -0.102 & -0.108 & -0.093 & -0.103 & -0.103 & -0.101 & -0.106 & -0.101 \\
\hline & {$[0.022]^{* *}$} & {$[0.027]^{* *}$} & {$[0.032]^{* *}$} & {$[0.027]^{* *}$} & {$[0.025]^{* *}$} & {$[0.006]^{* * *}$} & {$[0.035]^{* *}$} & {$[0.007]^{* * *}$} & {$[0.030]^{* *}$} & {$[0.041]^{* *}$} \\
\hline \multirow[t]{2}{*}{ Cash dividend dummy } & -0.041 & -0.037 & -0.045 & -0.042 & -0.041 & -0.042 & -0.035 & -0.046 & -0.038 & -0.035 \\
\hline & {$[0.039]^{* *}$} & {$[0.075]^{*}$} & {$[0.045]^{* *}$} & {$[0.156]$} & {$[0.137]$} & {$[0.091]^{*}$} & {$[0.031]^{* *}$} & {$[0.112]$} & {$[0.114]$} & {$[0.191]$} \\
\hline \multirow[t]{2}{*}{ Debt/assets } & 0.033 & 0.028 & 0.048 & 0.029 & 0.026 & 0.034 & 0.038 & 0.047 & 0.029 & 0.027 \\
\hline & {$[0.029]^{* *}$} & {$[0.091]^{*}$} & {$[0.039]^{* *}$} & {$[0.113]$} & {$[0.128]$} & {$[0.116]$} & {$[0.063]^{*}$} & {$[0.038]^{* *}$} & {$[0.124]$} & {$[0.114]$} \\
\hline \multirow[t]{2}{*}{ Industry sales growth } & 0.135 & 0.123 & 0.158 & 0.132 & 0.126 & 0.135 & 0.109 & 0.158 & 0.131 & 0.124 \\
\hline & {$[0.186]$} & [0.193] & {$[0.072]^{*}$} & [0.133] & [0.175] & {$[0.091]^{*}$} & [0.194] & {$[0.026]^{* *}$} & {$[0.022]^{* *}$} & {$[0.082]^{*}$} \\
\hline \multirow[t]{2}{*}{ Firm sales growth } & -0.076 & -0.074 & -0.081 & -0.075 & -0.072 & -0.078 & -0.071 & -0.081 & -0.074 & -0.073 \\
\hline & {$[0.023]^{* *}$} & {$[0.053]^{*}$} & {$[0.148]$} & {$[0.062]^{*}$} & {$[0.070]^{*}$} & {$[0.037]^{* *}$} & {$[0.148]$} & {$[0.186]$} & {$[0.085]^{*}$} & {$[0.086]^{*}$} \\
\hline \multirow[t]{2}{*}{ MKT } & -0.861 & -0.867 & -0.806 & -0.648 & -0.694 & -0.669 & -0.654 & -0.819 & -0.648 & -0.636 \\
\hline & [0.199] & {$[0.081]^{*}$} & {$[0.062]^{*}$} & {$[0.112]$} & {$[0.182]$} & {$[0.193]$} & {$[0.038]^{* *}$} & {$[0.074]$} & {$[0.056]^{*}$} & {$[0.180]$} \\
\hline \multirow[t]{2}{*}{ SMB } & 1.702 & 1.292 & 1.751 & 1.619 & 1.583 & 1.224 & 1.530 & 1.200 & 1.723 & 1.182 \\
\hline & {$[0.027]^{* *}$} & {$[0.064]^{*}$} & {$[0.030]^{* *}$} & {$[0.102]$} & {$[0.128]$} & {$[0.197]$} & {$[0.064]^{*}$} & {$[0.028]^{* *}$} & {$[0.092]^{*}$} & {$[0.209]$} \\
\hline \multirow[t]{2}{*}{ HML } & 1.051 & 1.001 & 1.032 & 1.315 & 0.982 & 1.093 & 1.094 & 1.416 & 1.015 & 0.994 \\
\hline & {$[0.030]^{* *}$} & {$[0.020]^{* *}$} & {$[0.169]$} & {$[0.161]$} & {$[0.034]^{* *}$} & {$[0.058]^{*}$} & {$[0.121]$} & {$[0.063]^{*}$} & {$[0.034]^{* *}$} & {$[0.036]^{* *}$} \\
\hline Number of observations & 19,154 & 19,154 & 19,154 & 19,154 & 19,154 & 19,154 & 19,154 & 19,154 & 19,154 & 19,154 \\
\hline Number of firms & 4,518 & 4,518 & 4,518 & 4,518 & 4,518 & 4,518 & 4,518 & 4,518 & 4,518 & 4,518 \\
\hline$p$-Value of $J$-test & 0.221 & 0.239 & 0.240 & 0.231 & 0.187 & 0.213 & 0.257 & 0.258 & 0.264 & 0.196 \\
\hline
\end{tabular}


Table 7

Financial restatements and the effect of insider control-ownership divergence on external finance constraints

This table presents the estimates from nonlinear GMM estimation of the investment Euler equation (Whited, 1992; Whited and $\mathrm{Wu}, 2006)$. The estimation is done on the model given by Eq. (8) in first differences with twice lagged instruments. The sample period used for estimation is 2000 to 2002. $\alpha_{2}$ and $\alpha_{3}$ are adjustment cost parameters, and $\mu$ is a mark-up. Control-ownership wedge is defined as the difference between insider control rights and cash-flow rights. Control-to-ownership ratio is defined as the ratio of insider control rights and cash-flow rights. Financial restatement is a dummy variable that equals one if the firm has a historical financial restatement record in the U.S. Government Accountability Office (GAO) database. Fraudulent restatement is a dummy variable that equals one if the firm has historical fraudulent financial restatements (prompted by the SEC or external auditors) recorded in the GAO database. Definitions of all the other variables are reported in Table 1. The $p$-values for the coefficients are reported in brackets. The $p$-values of the $J$-test (test of overidentifying restrictions) on model specification are reported in the last row. Significance at the $10 \%, 5 \%$, and $1 \%$ levels is indicated by $*, * *$, and $* * *$, respectively.

\begin{tabular}{|c|c|c|c|c|}
\hline & $(1)$ & $(2)$ & (3) & (4) \\
\hline \multirow[t]{2}{*}{$\alpha_{2}$} & 0.584 & 0.560 & 0.567 & 0.553 \\
\hline & {$[0.007]^{* * *}$} & {$[0.008]^{* * *}$} & {$[0.012]^{* *}$} & {$[0.014]^{* *}$} \\
\hline \multirow[t]{2}{*}{$\alpha_{3}$} & -0.451 & -0.437 & -0.433 & -0.425 \\
\hline & {$[0.040]^{* *}$} & {$[0.042]^{* *}$} & {$[0.042]^{* *}$} & {$[0.048]^{* *}$} \\
\hline \multirow[t]{2}{*}{ Mark-up $(\mu)$} & 1.063 & 1.086 & 1.082 & 1.136 \\
\hline & {$[0.037]^{* *}$} & {$[0.037]^{* *}$} & {$[0.018]^{* *}$} & {$[0.019]^{* *}$} \\
\hline \multirow[t]{2}{*}{ Control-ownership wedge (Wedge) } & 0.905 & 0.842 & & \\
\hline & {$[0.004]^{* * *}$} & {$[0.009]^{* * *}$} & & \\
\hline \multirow[t]{2}{*}{ Control-to-ownership ratio (Ratio) } & & & 0.412 & 0.372 \\
\hline & & & {$[0.005]^{* * *}$} & {$[0.007]^{* * *}$} \\
\hline \multirow[t]{2}{*}{ Wedge $\mathrm{x}$ Financial restatement dummy } & 0.239 & 0.253 & & \\
\hline & {$[0.000]^{* * *}$} & {$[0.019]^{* *}$} & & \\
\hline \multirow[t]{2}{*}{ Wedge $\mathrm{x}$ Fraudulent restatement dummy } & & 0.371 & & \\
\hline & & {$[0.005]^{* * *}$} & & \\
\hline \multirow[t]{2}{*}{ Ratio x Financial restatement dummy } & & & 0.082 & 0.060 \\
\hline & & & {$[0.006]^{* * *}$} & {$[0.018]^{* *}$} \\
\hline \multirow[t]{2}{*}{ Ratio x Fraudulent restatement dummy } & & & & 0.116 \\
\hline & & & & {$[0.002]^{* * *}$} \\
\hline \multirow[t]{2}{*}{ Financial restatement dummy } & 0.083 & 0.072 & 0.081 & 0.071 \\
\hline & {$[0.015]^{* *}$} & {$[0.034]^{* *}$} & {$[0.001]^{* * *}$} & {$[0.020]^{* *}$} \\
\hline \multirow[t]{2}{*}{ Fraudulent restatement dummy } & & 0.135 & & 0.126 \\
\hline & & {$[0.014]^{* *}$} & & {$[0.007]^{* * *}$} \\
\hline
\end{tabular}

(continued on the next page) 
Table 7

Financial restatements and the effect of insider control-ownership divergence on external finance constraints

(Continued)

\begin{tabular}{lllll}
\hline & \multicolumn{1}{c}{$(1)$} & $(2)$ & \multicolumn{1}{c}{$(3)$} & $(4)$ \\
\hline Cash flow/assets & -0.104 & -0.118 & -0.128 & -0.139 \\
& {$[0.019]^{* *}$} & {$[0.021]^{* *}$} & {$[0.017]^{* *}$} & {$[0.018]^{* *}$} \\
Cash dividend dummy & -0.040 & -0.038 & -0.055 & -0.051 \\
& {$[0.066]^{*}$} & {$[0.075]^{*}$} & {$[0.107]$} & {$[0.126]$} \\
Debt/assets & 0.026 & 0.025 & 0.030 & 0.028 \\
& {$[0.071]^{*}$} & {$[0.076]^{*}$} & {$[0.179]$} & {$[0.189]$} \\
Log assets & -0.052 & -0.055 & -0.069 & -0.072 \\
& {$[0.066]^{*}$} & {$[0.062]^{*}$} & {$[0.173]$} & {$[0.158]$} \\
Industry sales growth & 0.128 & 0.134 & 0.144 & 0.171 \\
Firm sales growth & {$[0.088]^{*}$} & {$[0.085]^{*}$} & {$[0.156]$} & {$[0.141]$} \\
& -0.075 & -0.071 & -0.052 & -0.045 \\
Analyst coverage & {$[0.161]$} & {$[0.188]$} & {$[0.033]^{* *}$} & {$[0.038]^{* *}$} \\
& -0.017 & -0.015 & -0.016 & -0.014 \\
MKT & {$[0.056]^{*}$} & {$[0.079]^{*}$} & {$[0.171]$} & {$[0.182]$} \\
& -0.794 & -0.746 & -0.926 & -0.840 \\
SMB & {$[0.042]^{* *}$} & {$[0.044]^{* *}$} & {$[0.038]^{* *}$} & {$[0.040]^{* *}$} \\
HML & 1.639 & 1.792 & 1.728 & 1.855 \\
Number of observations & {$[0.037]^{* *}$} & {$[0.054]^{*}$} & {$[0.040]^{* *}$} & {$[0.067]^{*}$} \\
Number of firms & 1.409 & 1.299 & 1.543 & 1.390 \\
& {$[0.035]^{* *}$} & {$[0.037]^{* *}$} & {$[0.038]^{* *}$} & {$[0.039]^{* *}$} \\
& 12,567 & 12,567 & 12,567 & 12,567 \\
& 3,935 & 3,935 & 3,935 & 3,935 \\
& 0.297 & 0.301 & 0.252 & 0.306 \\
\hline
\end{tabular}




\section{Table 8}

Institutional ownership and the effect of insider control-ownership divergence on external finance constraints

This table presents the estimates from nonlinear GMM estimation of the investment Euler equation (Whited, 1992; Whited and $\mathrm{Wu}, 2006)$. The estimation is done on the model given by Eq. (8) in first differences with twice lagged instruments. The sample period used for estimation is 1997 to 2002. $\alpha_{2}$ and $\alpha_{3}$ are adjustment cost parameters, and $\mu$ is a mark-up. Controlownership wedge is defined as the difference between insider control rights and cash-flow rights. Control-to-ownership ratio is defined as the ratio of insider control rights and cash-flow rights. Institutional investor ownership is computed as the number of shares held by all institutional investors divided by the total number of shares outstanding. Institutional blockholder ownership is calculated as the number of shares held by all institutional blockholders (defined as those who own at least 5\% of outstanding shares) divided by the total number of shares outstanding. Definitions of all the other variables are reported in Table 1 . The $p$ values for the coefficients are reported in brackets. The $p$-values of the $J$-test (test of overidentifying restrictions) on model specification are reported in the last row. Significance at the $10 \%, 5 \%$, and $1 \%$ levels is indicated by $*$, **, and ***, respectively.

\begin{tabular}{|c|c|c|c|c|c|c|c|c|}
\hline & $(1)$ & $(2)$ & (3) & (4) & (5) & (6) & (7) & (8) \\
\hline \multirow[t]{2}{*}{$\alpha_{2}$} & 0.707 & 0.727 & 0.627 & 0.625 & 0.714 & 0.737 & 0.630 & 0.600 \\
\hline & {$[0.014]^{* *}$} & {$[0.012]^{* *}$} & {$[0.024]^{* *}$} & {$[0.020]^{* *}$} & {$[0.019]^{* *}$} & {$[0.012]^{* *}$} & {$[0.023]^{* *}$} & {$[0.027]^{* *}$} \\
\hline \multirow[t]{2}{*}{$\alpha_{3}$} & -0.477 & -0.472 & -0.437 & -0.443 & -0.401 & -0.456 & -0.438 & -0.462 \\
\hline & {$[0.019]^{* *}$} & {$[0.014]^{* *}$} & {$[0.097]^{*}$} & {$[0.051]^{*}$} & {$[0.128]$} & {$[0.055]^{*}$} & {$[0.011]^{* *}$} & {$[0.052]^{*}$} \\
\hline \multirow[t]{2}{*}{ Mark-up $(\mu)$} & 1.039 & 1.032 & 1.029 & 1.018 & 1.099 & 1.057 & 1.097 & 1.054 \\
\hline & {$[0.027]^{* *}$} & {$[0.025]^{* *}$} & {$[0.032]^{* *}$} & {$[0.030]^{* *}$} & {$[0.032]^{* *}$} & {$[0.031]^{* *}$} & {$[0.024]^{* *}$} & {$[0.023]^{* *}$} \\
\hline \multirow[t]{2}{*}{ Control-ownership wedge (Wedge) } & 0.927 & 0.936 & 0.934 & 0.919 & & & & \\
\hline & {$[0.005]^{* * *}$} & {$[0.007]^{* * *}$} & {$[0.004]^{* * *}$} & {$[0.012]^{* *}$} & & & & \\
\hline \multirow[t]{2}{*}{ Control-to-ownership ratio (Ratio) } & & & & & 0.352 & 0.339 & 0.342 & 0.360 \\
\hline & & & & & {$[0.005]^{* * *}$} & {$[0.016]^{* *}$} & {$[0.009]^{* * *}$} & {$[0.007]^{* * *}$} \\
\hline \multirow[t]{2}{*}{ Institutional investor ownership } & -0.465 & -0.439 & & & -0.487 & -0.432 & & \\
\hline & {$[0.017]^{* *}$} & {$[0.021]^{* *}$} & & & {$[0.016]^{* *}$} & {$[0.023]^{* *}$} & & \\
\hline \multirow[t]{2}{*}{ Wedge x Institutional investor ownership } & & -0.942 & & & & & & \\
\hline & & {$[0.012]^{* *}$} & & & & & & \\
\hline \multirow[t]{2}{*}{ Institutional blockholder ownership } & & & -0.510 & -0.485 & & & -0.516 & -0.513 \\
\hline & & & {$[0.018]^{* *}$} & {$[0.024]^{* *}$} & & & {$[0.017]^{* *}$} & {$[0.028]^{* *}$} \\
\hline \multirow[t]{2}{*}{ Wedge x Institutional blockholder ownership } & & & & -0.964 & & & & \\
\hline & & & & {$[0.015]^{* *}$} & & & & \\
\hline \multirow[t]{2}{*}{ Ratio x Institutional investor ownership } & & & & & & -0.327 & & \\
\hline & & & & & & {$[0.018]^{* *}$} & & \\
\hline \multirow[t]{2}{*}{ Ratio x Institutional blockholder ownership } & & & & & & & & -0.339 \\
\hline & & & & & & & & {$[0.014]^{* *}$} \\
\hline
\end{tabular}

(continued on the next page) 


\section{Table 8}

Institutional ownership and the effect of insider control-ownership divergence on external finance constraints (Continued)

\begin{tabular}{|c|c|c|c|c|c|c|c|c|}
\hline & $(1)$ & $(2)$ & (3) & (4) & (5) & (6) & (7) & (8) \\
\hline \multirow[t]{2}{*}{ Cash flow/assets } & -0.107 & -0.121 & -0.110 & -0.114 & -0.109 & -0.117 & -0.108 & -0.114 \\
\hline & {$[0.026]^{* *}$} & {$[0.011]^{* *}$} & {$[0.021]^{* *}$} & {$[0.019]^{* *}$} & {$[0.027]^{* *}$} & {$[0.014]^{* *}$} & {$[0.020]^{* *}$} & {$[0.019]^{* *}$} \\
\hline \multirow[t]{2}{*}{ Cash dividend dummy } & -0.050 & -0.055 & -0.047 & -0.046 & -0.048 & -0.053 & -0.054 & -0.049 \\
\hline & {$[0.081]^{*}$} & {$[0.042]^{* *}$} & [0.121] & [0.122] & {$[0.072]^{*}$} & {$[0.039]^{* *}$} & {$[0.046]^{* *}$} & {$[0.126]$} \\
\hline \multirow[t]{2}{*}{ Debt/assets } & 0.033 & 0.034 & 0.034 & 0.039 & 0.025 & 0.028 & 0.028 & 0.027 \\
\hline & {$[0.071]^{*}$} & {$[0.086]^{*}$} & {$[0.062]^{*}$} & {$[0.028]^{* *}$} & {$[0.136]$} & [0.144] & [0.124] & {$[0.143]$} \\
\hline \multirow[t]{2}{*}{ Log assets } & -0.063 & -0.051 & -0.066 & -0.062 & -0.054 & -0.068 & -0.056 & -0.050 \\
\hline & {$[0.039]^{* *}$} & {$[0.072]^{*}$} & {$[0.034]^{* *}$} & {$[0.038]^{* *}$} & {$[0.070]^{*}$} & {$[0.032]^{* *}$} & {$[0.067]^{*}$} & {$[0.073]^{*}$} \\
\hline \multirow[t]{2}{*}{ Industry sales growth } & 0.123 & 0.129 & 0.134 & 0.126 & 0.132 & 0.125 & 0.124 & 0.138 \\
\hline & {$[0.134]$} & [0.124] & {$[0.039]^{* *}$} & {$[0.128]$} & {$[0.054]^{*}$} & [0.151] & {$[0.147]$} & {$[0.036]^{* *}$} \\
\hline \multirow[t]{2}{*}{ Firm sales growth } & -0.083 & -0.086 & -0.082 & -0.074 & -0.075 & -0.081 & -0.078 & -0.077 \\
\hline & {$[0.032]^{* *}$} & {$[0.030]^{* *}$} & {$[0.061]^{*}$} & {$[0.066]^{*}$} & {$[0.067]^{*}$} & {$[0.037]^{* *}$} & {$[0.035]^{* *}$} & {$[0.063]^{*}$} \\
\hline \multirow[t]{2}{*}{ Analyst coverage } & -0.018 & -0.016 & -0.012 & -0.011 & -0.013 & -0.014 & -0.017 & -0.015 \\
\hline & {$[0.029]^{* *}$} & {$[0.030]^{* *}$} & {$[0.073]^{*}$} & {$[0.030]^{* *}$} & {$[0.060]^{*}$} & {$[0.056]^{*}$} & {$[0.029]^{* *}$} & {$[0.071]^{*}$} \\
\hline \multirow[t]{2}{*}{ MKT } & -0.756 & -0.760 & -0.827 & -0.792 & -0.707 & -0.660 & -0.694 & -0.657 \\
\hline & {$[0.063]^{*}$} & [0.089]* & {$[0.031]^{* *}$} & {$[0.062]^{*}$} & {$[0.088]^{*}$} & {$[0.123]$} & {$[0.125]$} & {$[0.118]$} \\
\hline \multirow[t]{2}{*}{ SMB } & 1.223 & 1.272 & 1.211 & 1.322 & 1.149 & 1.313 & 1.190 & 1.291 \\
\hline & [0.159] & {$[0.082]^{*}$} & [0.147] & {$[0.038]^{* *}$} & {$[0.147]$} & {$[0.032]^{* *}$} & {$[0.155]$} & {$[0.074]^{*}$} \\
\hline \multirow[t]{2}{*}{ HML } & 1.301 & 1.137 & 1.097 & 1.091 & 1.306 & 1.207 & 1.254 & 1.248 \\
\hline & {$[0.031]^{* *}$} & {$[0.085]^{*}$} & [0.159] & [0.147] & {$[0.028]^{* *}$} & {$[0.077]^{*}$} & {$[0.029]^{* *}$} & {$[0.053]^{*}$} \\
\hline Number of observations & 19,154 & 19,154 & 19,154 & 19,154 & 19,154 & 19,154 & 19,154 & 19,154 \\
\hline Number of firms & 4,518 & 4,518 & 4,518 & 4,518 & 4,518 & 4,518 & 4,518 & 4,518 \\
\hline$p$-Value of $J$-test & 0.253 & 0.252 & 0.218 & 0.257 & 0.223 & 0.219 & 0.251 & 0.217 \\
\hline
\end{tabular}

